\title{
Estrogen receptors in human bladder cells regulate innate cytokine responses to differentially modulate uropathogenic $E$. coli colonization
}

Authors: Ayantika Sen1, Anil Kaul2, Rashmi Kaul1*

1Department of Biochemistry and Microbiology, Oklahoma State University Center for Health Sciences, 1111 West 17th Street, Tulsa, Oklahoma 74107, USA.

2Health Care Administration, Oklahoma State University Center for Health Sciences, 1111 West 17th Street, Tulsa, Oklahoma 74107, USA.

*Corresponding author. Address of correspondence: Department of Biochemistry \& Microbiology, Oklahoma State University Center for Health Sciences, 1111 West 17th Street, Tulsa, Oklahoma 74107-1898, Email: rashmi.kaul10@okstate.edu

\section{Abstract:}

The bladder epithelial cells elicit robust innate immune responses against urinary tract infections (UTIs) for preventing the bacterial colonization. Physiological fluctuations in circulating estrogen levels in women increase the susceptibility to UTI pathogenesis, often resulting in adverse health outcomes. Dr adhesin bearing Escherichia coli (Dr E. coli) cause recurrent UTIs in menopausal women and acute pyelonephritis in pregnant women. Dr $E$. coli bind to epithelial cells via host innate immune receptor CD55, under hormonal influence. The role of estrogens or estrogen receptors (ERs) in regulating the innate immune responses in the bladder are poorly understood. In the current study, we investigated the role of $\mathrm{ER} \alpha, \mathrm{ER} \beta$ and GPR30 in modulating the innate immune responses against Dr E. coli induced UTI using human bladder epithelial carcinoma 5637 cells (HBEC). Both ER $\alpha$ and ER $\beta$ agonist treatment in bladder cells induced a protection against Dr E. coli invasion via upregulation of TNF $\alpha$ and downregulation of CD55 and IL10, and these effects were reversed by action of $\mathrm{ER} \alpha$ and $\mathrm{ER} \beta$ antagoinsts. In contrast, the agonistmediated activation of GPR30 led to an increased bacterial colonization due to suppression 
of innate immune factors in the bladder cells, and these effects were reversed by the antagonist-mediated suppression of GPR30. Further, siRNA-mediated ER $\alpha$ knockdown in the bladder cells reversed the protection against bacterial invasion observed in the ER $\alpha$ positive bladder cells, by modulating the gene expression of TNF $\alpha, \mathrm{CD} 55$ and IL10, thus confirming the protective role of ER $\alpha$. We demonstrate for the first time a protective role of nuclear ERs, ER $\alpha$ and ER $\beta$ but not of membrane ER, GPR30 against Dr E. coli invasion in HBEC 5637 cells. These findings have many clinical implications and suggest that ERs may serve as potential drug targets towards developing novel therapeutics for regulating local innate immunity and treating UTIs.

Keywords: Bladder epithelial cells, Urinary Tract Infections, Dr E. coli, Estrogen Receptors, CD55, TNF $\alpha$, IL10

\section{Highlights:}

- Estrogen receptor (ER) subtypes regulate the gene expression of innate immune molecules, CD55, TNF $\alpha$ and IL10 in human bladder epithelial cells impacting the bacterial colonization by Dr E. coli.

- Activation of nuclear ER subtypes, ER $\alpha$ and ER $\beta$, upregulate the gene expression of proinflammatory cytokine, $\mathrm{TNF} \alpha$, but downregulate the gene expression of antiinflammatory cytokine, IL10, and Dr E. coli colonization receptor, CD55, thus leading to efficient bacterial clearance in human bladder cells.

- In contrast, activation of the membrane ER subtype, GPR30, shows opposite effects to $\mathrm{ER} \alpha$ and ER $\beta$ that were mediated on TNF $\alpha$, IL10 and CD55 gene expression, thus leading to impaired bacterial clearance of Dr E. coli in human bladder cells. 
- ER subtypes can serve as potential drug candidates for designing new therapies to boost or modulate the local immunity in the human bladder preventing the establishment of E. coli infections.

\section{Introduction:}

Urinary tract infection (UTI) may involve the infection of any part of the urinary tract. Ascending UTIs start with the infection of the urethra causing urethritis, may progress into the bladder to cause cystitis. In worst cases, if the host immunity is compromised in the bladder, the infection can advance to the kidneys causing acute or chronic pyelonephritis. Dr fimbriae bearing Escherichia coli (Dr E. coli)-induced recurrent UTI in menopausal women or acute pyelonephritis in pregnant women often lead to worst health outcome 1-3. Chronic pyelonephritis can cause end-stage kidney disease, as often observed in postmenopausal women suffering from a recurrent UTI 4, 5. Therefore, it is important to treat UTIs in the early stages of cystitis before the condition progresses to chronic cystitis or pyelonephritis. The innate immunity in the bladder epithelium is crucial as it serves as the first line of defense against uropathogens that can breach this protective barrier to colonize inside the bladder epithelial cells causing UTI 6,7. This bacterial colonization of the bladder epithelium triggers the secretion of both pro-inflammatory and antiinflammatory cytokines as part of the immediate innate immune responses generated by these epithelial cells 8-10. Most UTI cases are caused by uropathogenic E. coli (UPEC) that internalize and hide in the bladder epithelial cells using host proteins as their receptors to form intracellular bacterial reservoirs and cause recurrent UTIs 11, 12. Dr E. coli are among such UPECs that evades the host immune system by internalizing into the uroepithelial 
cells by binding to CD55 which is a complement regulatory protein expressed on host cell membranes 13 .

Postmenopausal and pregnant women have been reported to show a higher susceptibility to recurrent UTIs and have the worst disease outcome, suggesting hormonal etiology 1,14 . Several clinical and experimental studies have reported the involvement of estrogen in modulating the host immunity in the bladder and dictating the UTI disease outcome 15-17. Our previous studies have also shown that estrogen regulates CD55 expression that impacts the Dr E. coli colonization 1, 15. Estrogen or estrogen receptor (ER)-related mechanisms for modulating the innate immunity in the urinary tract remain poorly understood.

Robust innate immune responses in the bladder are generated by the epithelial cells and resident immune cells that play a major role in protecting the urinary tract from infections 6, 18. In response to bacterial infections, resident immune cells and epithelial cells of the bladder release pro-inflammatory cytokines, one of them being $\mathrm{TNF} \alpha$ 19-21. The local production of TNF $\alpha$ helps transepithelial migration of neutrophils that also assist in the bacterial clearance 7. Thus, TNF $\alpha$ is a critical cytokine of the innate immune system as it renders protection against intracellular bacterial infections and also shown to inhibit the development of many inflammatory diseases 22 . Once the infections are cleared, the epithelial cells and the resident immune cells of the bladder release anti-inflammatory cytokines, like IL10 to reduce the inflammation 23. IL10 is another important immunoregulatory cytokine that inhibits activation of macrophages and cytokine 
production, thus reducing local inflammation 24, 25. While higher TNF $\alpha$ expression is necessary for eliminating bacterial infections, induction of IL10 expression after bacterial clearance is required to prevent hyperinflammation that can be induced by uncontrolled $\mathrm{TNF} \alpha$ expression. Therefore, maintaining an equilibrium between TNF $\alpha$ and IL10 expression locally as well as systemically is crucial for restoring homeostasis state. Expression of both TNF $\alpha$ and IL10 in tissues and cells of the endometrium, brain, bone and gastrointestinal origin have been found to be differentially regulated by estrogen 26-28 via different ERs 29-35. Recently, we reported for the first time about the differential involvement of $\mathrm{ER} \alpha$ in modulating innate immunity in the bladder versus kidney during Dr E. coli induced UTI pathogenesis in an experimental mouse model. ER $\alpha$ played a protective role against infection in the kidney, however, the protection against infection in the bladder was mediated by ER subtypes other than ER $\alpha$, boosting local immunity via increased expression of TNF $\alpha$ 36. However, the involvement of estrogen and ERs in eliciting the TNF $\alpha$ or IL10 expression in the human bladder or kidney epithelium in response to Dr E. coli infection has not been studied till date.

Estrogen binds to its receptors, ER $\alpha, \mathrm{ER} \beta$ or GPR30, to form transcriptional factors that induce the transcription of several estrogen responsive genes involved in immune responses and inflammation 37. Differential distribution of these ER subtypes in various mouse and human tissues contribute to variable levels of expression of immune factors in different tissues 38-42. ER subtype involvement in modulating the local immunity in the human urinary tract in response to UTI has not been investigated so far. Thus, it is crucial 
to identify the precise role of each ER subtype in modulating the innate immune responses in the urinary tract that will result in efficient bacterial clearance

Therefore, in the current study we investigated the involvement of all three ER subtypes in regulating the colonization and invasion by Dr E. coli in human bladder cells by directly modulating the expression of innate immune cytokines, TNF $\alpha$ and IL10, and bacterial colonization receptor, CD55. This study was conducted in an in vitro model established with human bladder epithelial carcinoma (HBEC) 5637 cells. Understanding the ERregulated innate immune mechanisms operating in the human bladder cells will help us in designing the novel and effective immune based therapies that are highly needed for treating UTIs in women by boosting or regulating the local immune responses in the bladder.

\section{Materials and methods}

\subsection{Cell culture}

The research protocols followed in this study involving the use of human bladder cells and

Dr E. coli strain were approved by the Institutional Biosafety Committee (IBC) of Oklahoma State University Center for Health Sciences. This study did not require any other ethical board approval because no human subjects or animal tissues were used.

Human bladder epithelial carcinoma (HBEC) 5637 cells (kindly provided by Doris M. Benbrook, University of Oklahoma Health Sciences Center) were cultured and maintained in sterile Roswell Park Memorial Institute (RPMI) 1640 medium (Invitrogen, Carlsbad, CA) supplemented with $10 \%$ fetal bovine serum (FBS) (Atlanta Biologicals, Flowery 
Branch, GA), $100 \mathrm{U} / \mathrm{ml}$ penicillin, $100 \mu \mathrm{g} / \mathrm{ml}$ streptomycin (Invitrogen, Carlsbad, CA), 1 $\mathrm{mM}$ sodium pyruvate (Invitrogen, Carlsbad, CA) and 1\% GlutaMAX ${ }^{\mathrm{TM}}$ Supplement (Invitrogen, Carlsbad, CA) incubated at $37^{\circ} \mathrm{C}$ in a humidified atmosphere (95\%) containing $5 \% \mathrm{CO}_{2}$.

\subsection{Hormonal drug treatment of bladder cells}

HBEC 5637 cells were plated at different densities in 6-well, 12-well, 24-well plates and 96-well plates for various assays and were allowed to grow overnight (18-24 hours). Before hormone drug treatment, the cells were subjected to serum starvation for 20-24 hours. After serum starvation, the cells were incubated with different doses of various drugs at for another 24 hours till further experimentation. The hormonal drugs that were used include, Propylpyrazole Triol (PPT), Methyl-piperidino-pyrazole (MPP), 2,3-bis (4Hydroxyphenyl) propionitrile (DPN), 4-[2-Phenyl-5,7-bis(trifluoromethyl)pyrazolo[1,5a]pyrimidin-3-yl]pheno) (PHTPP), ( \pm )-1-[(3aR*,4S*,9bS*)-4-(6-Bromo-1,3-benzodioxol-

5-yl)-3a,4,5,9b-tetrahydro-3H-cyclopenta[c]quinolin-8-yl]-ethanone $\quad(\mathrm{G} 1) \quad$ and $\left(3 \mathrm{aS} *, 4 \mathrm{R}^{*}, 9 \mathrm{bR} *\right)-4-(6-B r o m o-1,3-$ benzodioxol-5-yl)-3a,4,5,9b-3H-

cyclopenta[c]quinoline (G15). These drugs were purchased from Cayman Chemicals (Ann Arbor, MI). The stock solutions were prepared in DMSO and diluted to the required working concentrations in serum-free media. The vehicle control (C) included in the assay had only serum free culture medium with DMSO (0.01\% vol/vol).

\subsection{Gene-silencing by siRNA transfection}


HBEC 5637 cells were grown to $60 \%$ confluency before transfection with either esr1targeting siRNAs (ID-s4825, Cat. no. 4392420, Ambion, Waltham, MA) or non-specific (negative control or NC) siRNA (Cat. no. 4390843, Ambion, Waltham, MA) using lipofectamine reagent (Invitrogen, Waltham, MA) following the manufacturer's instructions. After 48 hours, esrl gene silencing was confirmed by both quantitative realtime RT-PCR and immunofluorescence staining. These esrl-/- bladder cells were subjected to further experimentation.

\subsection{Cell viability assay}

HBEC 5637 cells were grown overnight in 96-well plates (50,000 cells/ well) and treated with different concentrations of either hormonal drugs for 24 hours or siRNA transfection reagent for 48 hours. The cells were then treated with MTT solution $(0.5 \mathrm{mg} / \mathrm{ml}$ in serum free RPMI media) for 2 hours at $37^{\circ} \mathrm{C}$. The formazan compound formed in the cells after 2 hours was solubilized in a 3:1 mixture of DMSO and serum free RPMI media and the OD was measured at $540 \mathrm{~nm}$. The non-toxic drug doses that were selected for the treatment of cells in experimental assays were as follows: PPT $(0.01 \mu \mathrm{M}, 0.1 \mu \mathrm{M}$, and $1 \mu \mathrm{M}), \mathrm{MPP}$ (0.01 $\mu \mathrm{M}, 0.1 \mu \mathrm{M}$, and $1 \mu \mathrm{M}), \mathrm{DPN}(0.01 \mu \mathrm{M}, 0.1 \mu \mathrm{M}, 1 \mu \mathrm{M}$ and $10 \mu \mathrm{M}), \operatorname{PHTPP}(0.001$ $\mu \mathrm{M}, 0.01 \mu \mathrm{M}, 0.05 \mu \mathrm{M}$ and $0.1 \mu \mathrm{M}), \mathrm{G} 1(0.001 \mu \mathrm{M}, 0.01 \mu \mathrm{M}, 0.1 \mu \mathrm{M})$ and $\mathrm{G} 15(0.1 \mu \mathrm{M}$, $1 \mu \mathrm{M}, 2.5 \mu \mathrm{M})$. The optimum non-toxic concentration of esrl siRNA and negative control siRNA used for experimental assays was $10 \mathrm{nM}$.

\subsection{Preparation of bacterial inoculum}


The presence of Dr adhesin on Dr E. coli strain-IH11128 (O75:K5: H- strain) was confirmed by hemagglutination of human O group erythrocytes as described previously 13. Isolated colonies of Dr E. coli and its isogenic mutant Dr - E. coli from overnight cultures were resuspended in serum free RPMI media. A suspension of Dr E. coli with an OD of 0.5 measured at $600 \mathrm{~nm}(4.5 \times 108 \mathrm{cfu} / \mathrm{ml})$ was prepared for the infection of bladder cells.

\subsection{Determination of bacterial invasion by Gentamicin Protection Assay}

HBEC 5637 cells were grown overnight in 24-well plates (150,000 cells/well). Upon reaching $70 \%$ confluency, the cells were subjected to either 24-hour drug treatment or 48hour of siRNA transfection. The cells were then infected with Dr E. coli suspension at a multiplicity of infection (MOI) of approximately 30. The cell culture plates were centrifuged at $500 \mathrm{x}$ g and incubated for 1 hour at $37^{\circ} \mathrm{C}$. Bacterial suspension was removed and the cells were washed once with sterile PBS. To kill extracellular bacteria, the cells were incubated with $100 \mu \mathrm{g} / \mathrm{ml}$ gentamicin for 1 hour. Gentamicin was aspirated and the cells were washed with sterile PBS to remove any residual gentamicin. The cells were then lysed with buffer containing $1 \%$ Triton X-100 in PBS. The cell lysates were plated on LB agar plates and incubated at $37^{\circ} \mathrm{C}$ overnight to determine the number of viable bacteria internalized in the cells. Bacterial colonies were counted and represented as colonyforming units (CFU). The results of gentamicin protection assay were reported as percentage of bacterial invasion in treated cells relative to bacterial invasion in untreated control (C) cells (considered as 100\%). The gentamicin protection assay for each treatment condition was performed 6-8 times with 3 replicates per experiment. 


\subsection{RNA isolation, cDNA synthesis and quantitative RT-PCR analyses}

Total RNA was isolated from drug treated or siRNA transfected HBEC 5637 cells using TRIzol reagent (Life Technologies, Grand Island, NY) and cDNA was synthesized. Quantitative RT-PCR was performed using PowerUp ${ }^{\mathrm{TM}}$ SYBR ${ }^{\circledR}$ Green Master Mix (Applied Biosystems, Foster City, CA). The expression levels of target genes, cd55, tnfa and $i l 10$ were normalized to the endogenous control gene, gapdh and to the experimental control (C) and reported as 2- $\Delta \Delta \mathrm{Ct}$ values. Quantitative RT-PCR was carried out using 7500 Real-Time PCR System (Applied Biosystems, Foster City, CA). The primer pairs were purchased from Integrated DNA Technologies (Coralville, IA) and are listed below:

cd55 (Forward primer - 5' TTTCCAGGACAACCAAGCATT 3', Reverse primer - 5' ACACGTGTGCCCAGATAGA 3’),

tnfa (Forward primer- 5' TGTAGCCCATGTTGTAGCAAAC 3', Reverse primer- 5' AGAGGACCTGGGAGTAGATGA 3')

illo (Forward primer- 5' AATGAAGGATCAGCTGGACAAC 3', Reverse primer- 5' CCAGGTAAAACTGGATCATCTCAG 3')

gapdh (Forward primer- 5' GCACCGTCAAGCTGA 3', Reverse primer- 5' ACTCAGCGCCAGCATC 3'),

esrl (Forward primer- 5' CCAACCAGTGCACCATTGAT 3', Reverse primer- 5' GGTCTTTTCGTATCCCACCTTT 3'), 
esr2 (Forward primer- 5' GGCAGAGGACAGTAAAAGCA3', Reverse primer- 5' GGACCACACAGCAGAAAGAT3'),

gperl (Forward primer- 5' GTACTTCATCAACCTGGCGGTG3', Reverse primer- 5' TCATCCAGGTGAGGAAGAAGACG3’)

\subsection{Immunofluorescence staining of cells for epifluorescent microscopy}

HBEC 5637 cells were grown overnight on glass coverslips (\#1.5) placed inside in each well of 12 -well plate $\left(150,000\right.$ cells/well) incubated overnight at $37^{\circ} \mathrm{C}$ with $5 \% \mathrm{CO}_{2}$. The cells were then subjected to either 24-hour drug treatment or 48-hour of siRNA transfection. Upon reaching 70-75\% confluency, the cells were rinsed 3 times with icecold PBS and fixed in 4\% paraformaldehyde for 1 hour at room temperature. Only the cells to be stained for nuclear proteins were permeabilized with $0.1 \%$ Triton $\mathrm{X}-100$ for 10 minutes at room temperature. Both permeabilized and non-permeabilized cells were then incubated in $3 \%$ BSA for 30 minutes at room temperature to block non-specific binding sites. After blocking, the cells were incubated with primary antibodies diluted in $3 \%$ BSA and left overnight at $4^{\circ} \mathrm{C}$. The primary antibodies used were rabbit anti-human ER $\alpha$ (ab108398) at 1:50 dilution, rabbit anti-human $\operatorname{ER} \beta(\mathrm{ab3577})$ at 1:2000 dilution, rabbit anti-human GPR30 (ab39742) at 1:400 dilution and rabbit anti-human CD55 (ab1422) at 1:200 dilution. Next day, the cells were washed three times with PBS and further incubated with FITC labelled goat anti-rabbit IgG (ab 150077) prepared in 3\% BSA at a dilution of 1:500 left for 1 hour in the dark at room temperature. After a washing step, the coverslips were mounted on a glass slide with Prolong Diamond Antifaded mounting reagent 
(Thermofisher, Waltham, MA) containing DAPI to counterstain nuclei. Samples were imaged using a Nikon Eclipse Ts2R epifluorescent microscope.

\subsection{Western Blotting Assays}

Drug treated or siRNA transfected HBEC 5637 cells were collected from 6-well plates (containing 300,000 cells/well) using cell dissociation buffer (Life Technologies, Waltham, MA). The cells were lysed with RIPA lysis buffer supplemented with Halt ${ }^{\mathrm{TM}}$ Protease and Phosphatase Inhibitor Cocktail (Thermofisher, Waltham, MA) and phenylmethylesulfonyl fluoride (Thermofisher, Waltham, Ma). The total protein concentration in each cell lysate was measured using Pierce BCA Protein Assay Kit (Thermofisher, Waltham, MA). The cell lysates containing approximately $20 \mu \mathrm{g}$ of protein were resolved on Novex ${ }^{\mathrm{TM}}$ NuPAGETM 4-12\% Bis-Tris Protein Gels (Invitrogen, Waltham, MA). The separated proteins were transferred to nitrocellulose membranes that were subsequently blocked using 5\% non-fat dry milk diluted in TBST (10 mM Tris-HCL, $100 \mathrm{mM}$ $\mathrm{NaCl}, 0.2 \%$ Tween-20) at room temperature for 2 hours. After blocking, the membranes were incubated with rabbit anti-human CD55 antibody (ab133684) at a dilution of 1:5000 and rabbit anti-human $\beta$-actin antibody (ab8227) at a dilution of $1: 1000$ overnight at $4^{\circ} \mathrm{C}$. Both antibodies were diluted in TBST containing 5\% milk. Membranes were subsequently probed with an alkaline phosphatase conjugated goat anti-rabbit IgG (7054S, Cell Signaling) used at a dilution of 1:1000 in TBST containing 5\% milk at room temperature for 2 hours. The immunoreactivity was carried out using an Enhanced Chemiluminescence reagent (Fisher Scientific, Hampton, NH). 


\subsection{Statistics}

GraphPad Prism 7.03 (Graph Pad software Inc.) was used for statistical comparisons between experimental groups. Statistical analysis for more than two experimental groups was conducted using parametric one-way ANOVA followed by Dunnet's post-hoc test, for multiple comparisons. A p-value of less than 0.05 was considered significant.

\section{Results:}

\subsection{HBEC 5637 cells express CD55 which serves as a binding ligand for Dr E. coli during cell invasion and infection}

Before establishing the in vitro model of UTI pathogenesis using HBEC 5637 cells, we confirmed the expression of CD55 in these cells as CD55 serves as colonization receptor for Dr E. coli 13, 43. We observed a high expression of CD55 protein in these cells (Figure 1 a). In order to confirm the colonization and invasion by Dr E. coli in these cells is mediated by binding to CD55, we blocked CD55 expression in these cells by pre-treatment of cells with CD55 antibody prior to bacterial invasion. Dr E. coli invasion in cells was significantly reduced in a dose-dependent manner by antibody dilutions of 1:200 ( $\mathrm{P}<0.01)$, 1:100 ( $\mathrm{P}<0.001), 1: 50$ and 1:20 ( $\mathrm{P}<0.0001)$ (Figure $1 \mathrm{~b})$, confirming that CD55 serves as the colonization receptor for Dr E. coli in 5637 cells. To further confirm that bacterial invasion in HBEC cells was facilitated by the presence of Dr fimbriae, we included Dr- $E$. coli (an isogenic mutant for Dr fimbriae) strain as a negative control in the bacterial invasion assay. Dr E. coli invasion in cells pre-treated with CD55 antibody was found to be significantly low $(\mathrm{P}<0.0001)$ when compared to antibody untreated Dr E. coli infected 
cells (Figure $1 \mathrm{c}$ ), confirming that bacterial invasion in HBEC 5637 cells is mediated via CD55. Further, a significantly low $(\mathrm{P}<0.0001)$ Dr $^{-}$E. coli invasion was observed in antibody untreated cells and in cells pre-treated with CD55 antibody, when compared to untreated Dr E. coli infected cells (Figure $1 \mathrm{c}$ ). This observation further confirms that the presence of both Dr fimbriae and CD55 are crucial for Dr E. coli invasion in HBEC 5637 cells.

a.

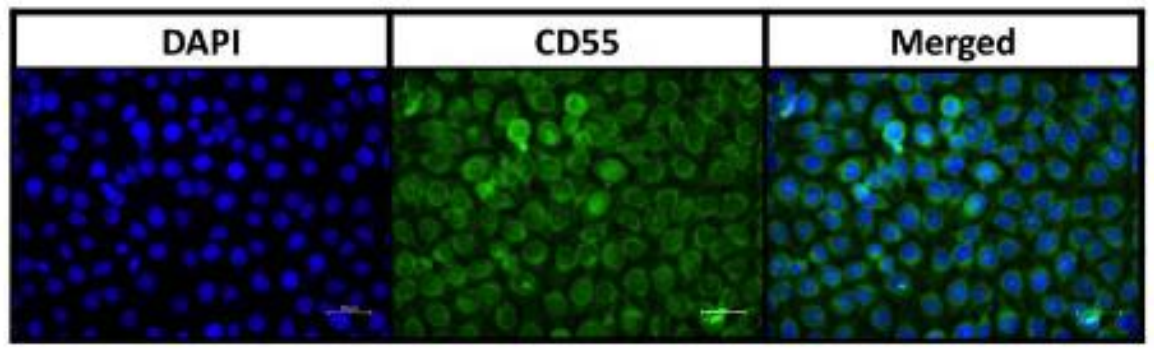

b.

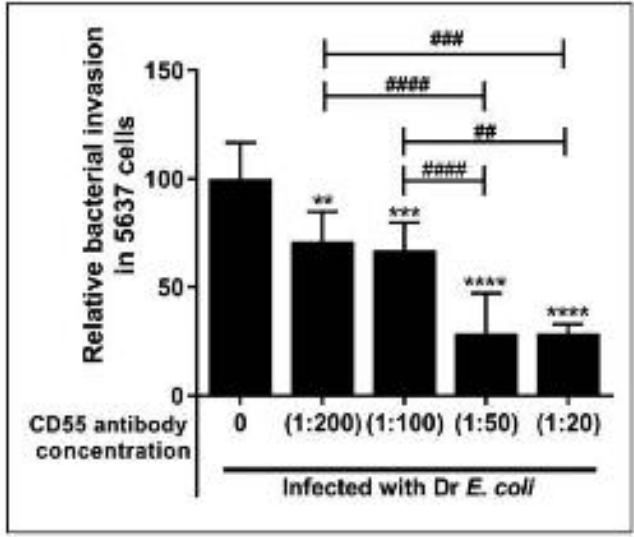

c.

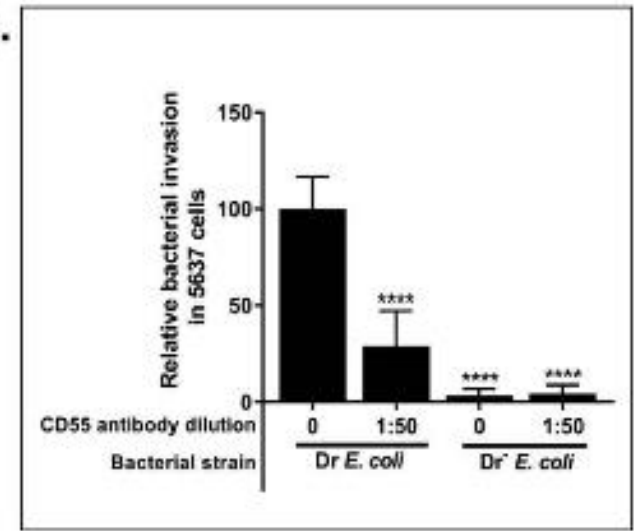

Figure 1: (a) Expression of CD55 in HBEC 5637 cells detected by immunofluorescence staining. (b) Relative invasion by Dr E. coli in cells pre-incubated with CD55 antibody for blocking CD55 receptor. Cells incubated with CD55 antibody had significantly low bacterial invasion. (c) Relative invasion by Dr E. coli and Dr- E. coli in HBEC 5637 cells with or without CD55 antibody pre-treatment. $\mathrm{Dr}^{-} E$. coli showed significantly low bacterial invasion as compared to Dr E. coli. $(* * P<0.01$, $* * * P<0.001$, $* * * * P<0.0001$ indicate significant differences

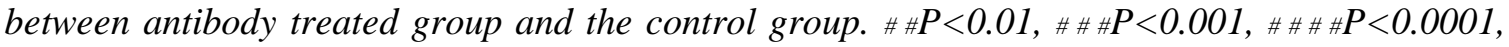
indicate significant differences between antibody treated groups as indicated) 


\subsection{HBEC 5637 cells express all three ER subtypes, ERa, ERß and GPR30}

The mRNA and protein expressions of the three ER subtypes in HBEC 5637 cells was assessed. The expression of esr2 mRNA was 1.5-fold higher than expression of esr 1 mRNA (P < 0.001; Figure 2 a). ER $\beta$ protein expression was 2 -fold higher than $\mathrm{ER} \alpha(\mathrm{P}<$ 0.0001; Figure 2 b). Similarly, gper1 mRNA expression was also 2 fold higher than esr 1 mRNA ( $P<0.001$; Figure 2 a). GPR30 protein expression in cells was 2.5 fold higher than ER $\alpha$ expression $(\mathrm{P}<0.001$; Figure $2 \mathrm{~b})$. A significantly higher mRNA $(\mathrm{P}<0.05)$ and protein $(\mathrm{P}<0.0001)$ expression of GPR30 was also observed in these cells when compared to $\operatorname{ER} \beta$ (Figures $2 \mathrm{a}$ and $2 \mathrm{~b}$ ).

a.

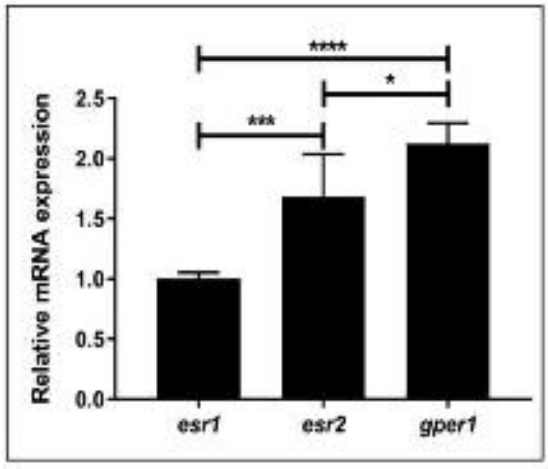

b.

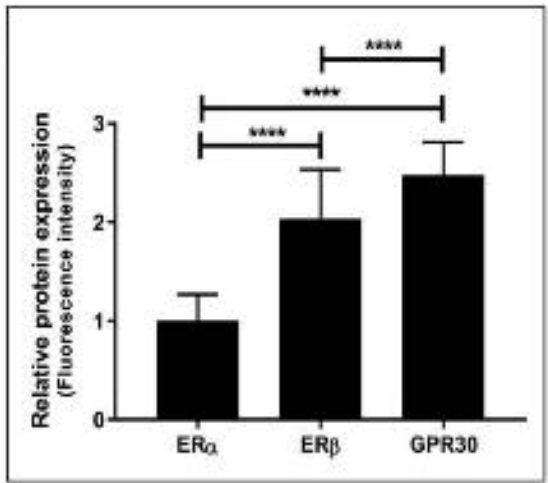

c.

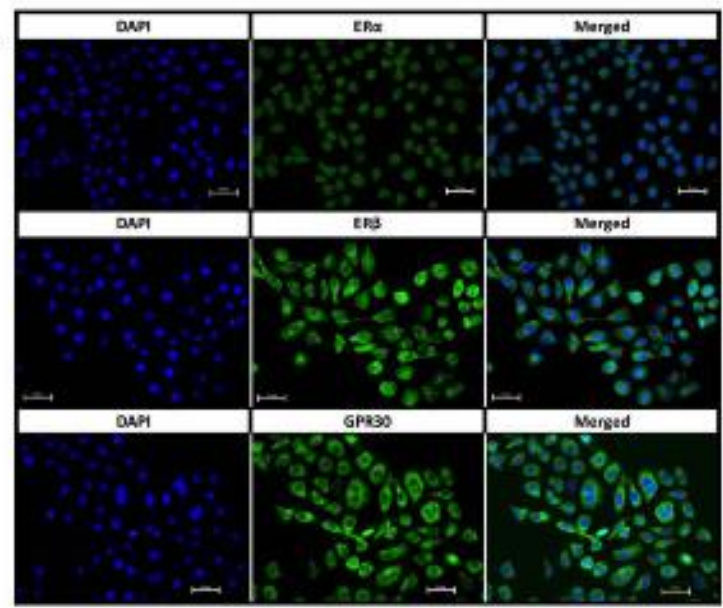


Figure 2: Expression of estrogen receptor subtypes in HBEC 5637 cells. (a) esr2 and gper mRNA expression were significantly higher compared to esrl mRNA expression levels. (b) ER $\beta$ and GRP30 protein levels were also significantly higher than ER $\alpha$. (c) Representative images showing the protein expression of estrogen receptors detected by immunofluorescence staining. $\left({ }^{*} P<0.05, * * * P<0.001, * * * * P<0.0001\right.$ indicate significant differences between $E R \alpha, E R \beta$ and GRP30 expression)

\subsection{Drug-induced modulation of ER subtype activity in HBEC 5637 cells differentially}

regulate Dr E. coli invasion

We determined the role of each ER subtype in modulating the Dr E. coli invasion in HBEC 5637 cells pre-treated with specific ER subtype agonists or antagonists.

ER $\alpha$ agonist, PPT treatment of cells led to a dose-dependent significant inhibition of bacterial invasion (70-85\%) observed at all three doses, $0.01 \mu \mathrm{M}, 0.1 \mu \mathrm{M}$ and $1 \mu \mathrm{M}(\mathrm{P}<$ 0.0001) compared to vehicle treated control (Figure 3 a). ER $\alpha$ antagonist, MPP treatment reversed the protection mediated by PPT in a dose-dependent manner. However, MPP treatment of cells resulted in a partial protection with only $40-60 \%$ reduction in bacterial invasion at all three doses, $0.01 \mu \mathrm{M}, 0.1 \mu \mathrm{M}$ and $1 \mu \mathrm{M}$ when compared to control $(\mathrm{P}<$ 0.0001) (Figure 3 a).

ER $\beta$ agonist, DPN treatment of cells also resulted in a significant reduction in bacterial invasion ranging between $30-70 \%$ at all doses $(\mathrm{P}<0.0001)$, with $1 \mu \mathrm{M}$ DPN being the most protective resulting in $70 \%$ reduction in bacterial invasion. In contrast, ER $\beta$ antagonist, PHTPP treatment reversed the protection mediated by DPN. PHTPP led to a significant increase in bacterial invasion ranging between $20-55 \%$ at doses $0.001 \mu \mathrm{M}(\mathrm{P}<$ 
$0.0001), 0.05 \mu \mathrm{M}(\mathrm{P}<0.0001)$ and $0.1 \mu \mathrm{M}$ when compared to control $(\mathrm{P}<0.05)$, except at $0.01 \mu \mathrm{M}$ dose, which was comparable to control.

In contrast, the activation of GPR30 by agonist G1 treatment of cells did not result in any protection as observed with ER $\alpha$ and $\operatorname{ER} \beta$ activation. Increased bacterial invasion ranging between 10-20\% was observed in cells at all the doses of $\mathrm{G} 1,0.001 \mu \mathrm{M}, 0.1 \mu \mathrm{M}$ and $1 \mu \mathrm{M}$ when compared to control (P > 0.05). However, blocking of GPR30 in cells by antagonist G15 resulted in a significantly low bacterial invasion ranging between $20-50 \%$ at all doses, $0.1 \mu \mathrm{M}(\mathrm{P}<0.0001), 1 \mu \mathrm{M}(\mathrm{P}<0.01)$ and $2.5 \mu \mathrm{M}(\mathrm{P}<0.0001)$.

In summary, ER $\alpha$ agonist, PPT was the most efficient in protecting against bacterial invasion in bladder cells, followed by ER $\beta$ agonist, DPN and GPR30 antagonist, G15. The least protection was mediated by suppression of ER $\beta$ by antagonist, PHTPP, followed by activation of GPR30 by agonist, G1 and suppression of ER $\alpha$ by its antagonist, MPP. 
a.

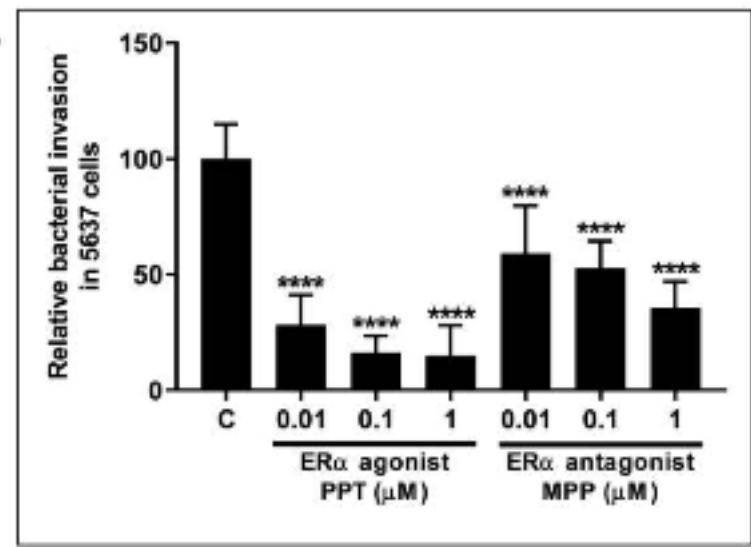

b.

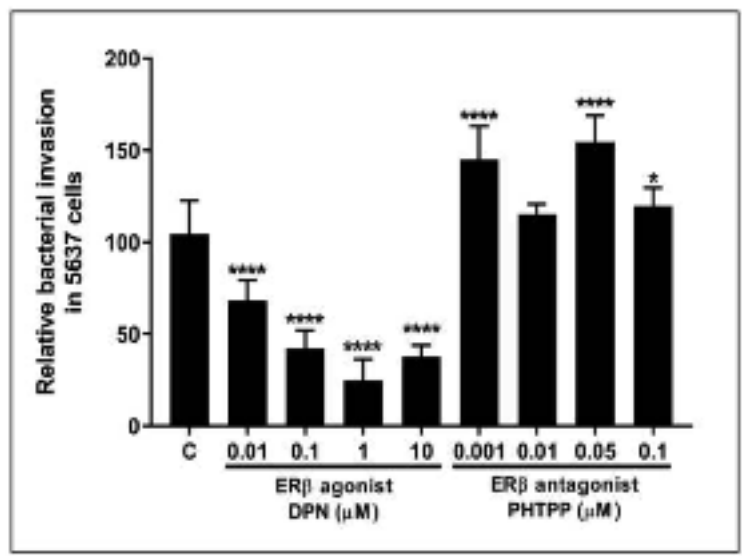

c.

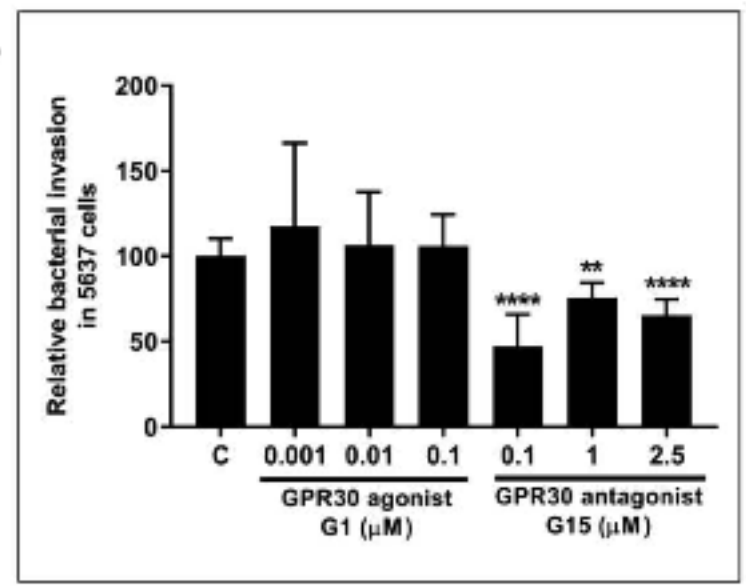

Figure 3: Relative invasion by Dr E. coli in HBEC 5637 cells pre-treated with (a) ERa agonist PPT and ER $\alpha$ antagonist MPP, (b) ERß agonist DPN and ERß antagonist PHTPP, (c) GPR30 agonist G1 and GPR30 antagonist G15. PPT was most efficient in inhibiting bacterial invasion followed by DPN and G15. PHTPP was least effective in inhibiting bacterial invasion followed by G1 and MPP. $(* P<0.05$, ***P<0.001, ****P<0.0001 indicate significant differences between drug treated groups and vehicle control $(C)$ group) 


\subsection{Drug- induced modulation of ER subtype activity in HBEC 5637 cells differentially regulates CD55 expression}

In our previous experiments, treatment of cells with specific ER subtype agonists or antagonists led to differential protection against bacterial invasion. Hence, we further investigated the effects of these drugs on CD55 mRNA and protein expression as CD55 facilitates Dr E. coli colonization in cells.

ER $\alpha$ agonist, PPT treatment significantly reduced $c d 55$ mRNA expression in HBEC 5637 cells at doses $0.01 \mu \mathrm{M}, 0.1 \mu \mathrm{M}$ and $1 \mu \mathrm{M}(\mathrm{P}<0.0001)$ (Figure 4 a) when compared to control. ER $\alpha$ antagonist, MPP treatment also significantly reduced $c d 55$ mRNA expression in these cells at doses $0.01 \mu \mathrm{M}, 0.1 \mu \mathrm{M}$ and $1 \mu \mathrm{M}(\mathrm{P}<0.0001)$ (Figure $4 \mathrm{a})$, however, not to the extent observed in PPT treated cells, explaining the partial reversal of protection.

CD55 protein expression was significantly reduced in PPT treated cells at doses $0.01 \mu \mathrm{M}$ $(\mathrm{P}<0.001), 0.1 \mu \mathrm{M}(\mathrm{P}<0.0001)$ and $1 \mu \mathrm{M}$ when compared to control, $(\mathrm{P}<0.001)$ (Figure 4 b). In contrast, MPP treatment of cells increased CD55 protein expression when compared to CD55 expression by PPT, explaining the reversal of protection. However, when compared to control, MPP treatment significantly reduced CD55 protein expression compared to control at $0.1 \mu \mathrm{M}(\mathrm{P}<0.01)$ and $1 \mu \mathrm{M}(\mathrm{P}<0.0001)$ (Figure $4 \mathrm{~b})$.

ER $\beta$ agonist, DPN treatment of cells significantly reduced $c d 55$ mRNA expression at doses $0.01 \mu \mathrm{M}(\mathrm{P}<0.05), 0.1 \mu \mathrm{M}(\mathrm{P}<0.01), 1 \mu \mathrm{M}(\mathrm{P}<0.0001)$ and $1 \mu \mathrm{M}(\mathrm{P}<0.05)$ when compared to control (Figure $4 \mathrm{c}$ ). Expression of $c d 55$ mRNA in response to ER $\beta$ antagonist, 
PHTPP treatment of cells was higher than $1 \mu \mathrm{M}$ DPN but comparable to control at dose $0.001 \mu \mathrm{M}$ and $0.05 \mu \mathrm{M}(\mathrm{P}>0.05)$. Further, PHTPP treatment significantly reduced $c d 55$ mRNA expression in cells at doses $0.01 \mu \mathrm{M}(\mathrm{P}<0.05)$, and $0.1 \mu \mathrm{M}(\mathrm{P}<0.001)$ (Figure 4 c).

DPN treatment of cells reduced CD55 protein expression at all the doses, however a significant reduction was only observed at $0.01 \mu \mathrm{M}(\mathrm{P}<0.05)$ and $1 \mu \mathrm{M}(\mathrm{P}<0.001)$ (Figure $4 \mathrm{~d})$. In contrast, CD55 protein expression in ER $\beta$ antagonist, PHTPP treated cells was found to be comparable to control at all doses except for $0.01 \mu \mathrm{M}$, which significantly reduced $(\mathrm{P}<0.0001)$ the $\mathrm{CD} 55$ expression (Figure $4 \mathrm{~d})$. This significant reduction in CD55 protein expression in response to $0.01 \mu \mathrm{M}$ PHTPP treatment in cells corresponded with the decrease in bacterial invasion observed at this dose. Changes in both CD55 mRNA and protein expression in response to different doses of DPN and PHTPP were found to be directly correlating with the changes in bacterial invasion at the same doses.

GPR30 agonist, G1 treatment of cells significantly increased $c d 55$ mRNA expression at doses $0.001 \mu \mathrm{M}(\mathrm{P}<0.05)$ and $0.01 \mu \mathrm{M}(\mathrm{P}<0.001)$ when compared to control (Figure 4 e). However, $c d 55$ mRNA expression levels in response to $0.01 \mu \mathrm{M}$ G1 treatment was similar to control. In contrast, GPR30 antagonist, G15 treatment reduced $c d 55$ mRNA expression at all doses, but significantly only at $0.1 \mu \mathrm{M}(\mathrm{P}<0.001)$ and $2.5 \mu \mathrm{M}(\mathrm{P}<0.05)$ (Figure 4 e). 
Further, G1 treatment of cells reduced CD55 protein expression at all doses as compared to control but significant reduction was only observed at doses $0.01 \mu \mathrm{M}(\mathrm{P}<0.001)$ and $0.1 \mu \mathrm{M}(\mathrm{P}<0.01)$ (Figure $4 \mathrm{f})$. However, GPR30 antagonist, G15 treatment of cells significantly reduced CD55 protein expression at all three doses, $0.1 \mu \mathrm{M}(\mathrm{P}<0.0001), 1$ $\mu \mathrm{M}(\mathrm{P}<0.001)$ and $2.5 \mu \mathrm{M}(\mathrm{P}<0.0001)$ (Figure $4 \mathrm{f}) . \mathrm{CD} 55$ protein expression in $\mathrm{G} 15$ treated cells was lower than that observed in G1 treated cells, explaining the observed protection against bacterial invasion mediated by G15, but not by G1. 
a.

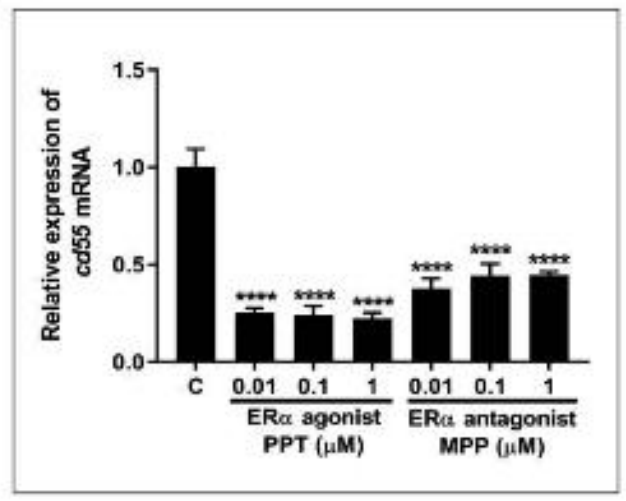

c.

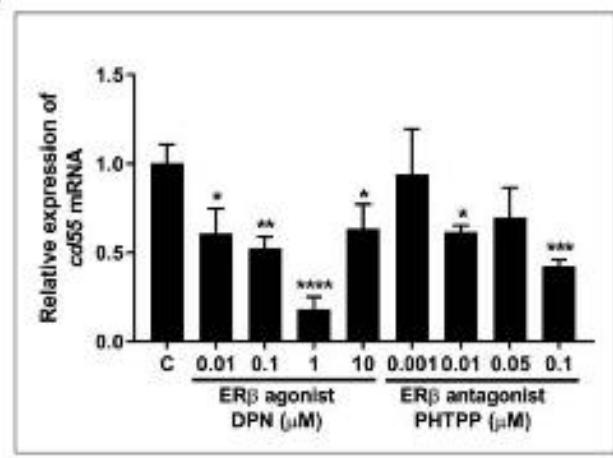

e.

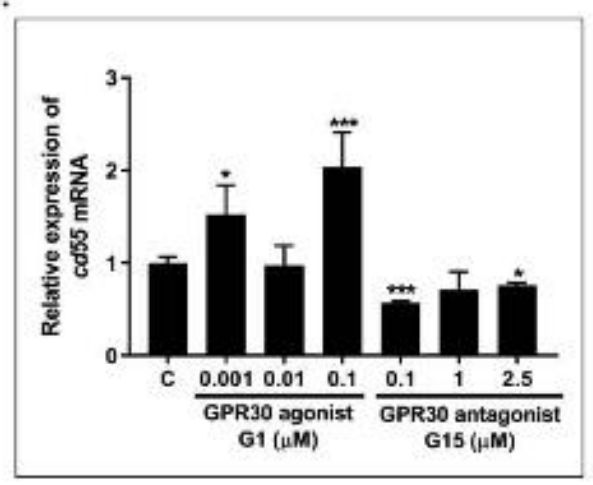

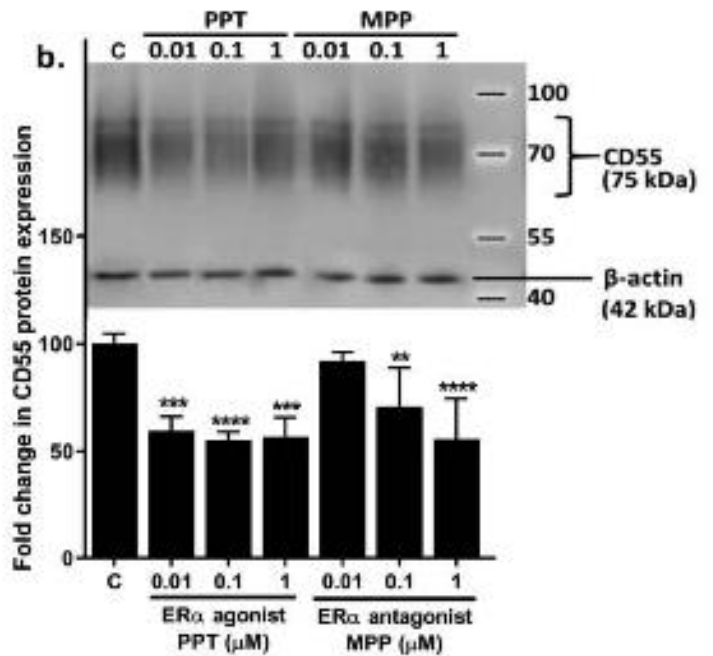
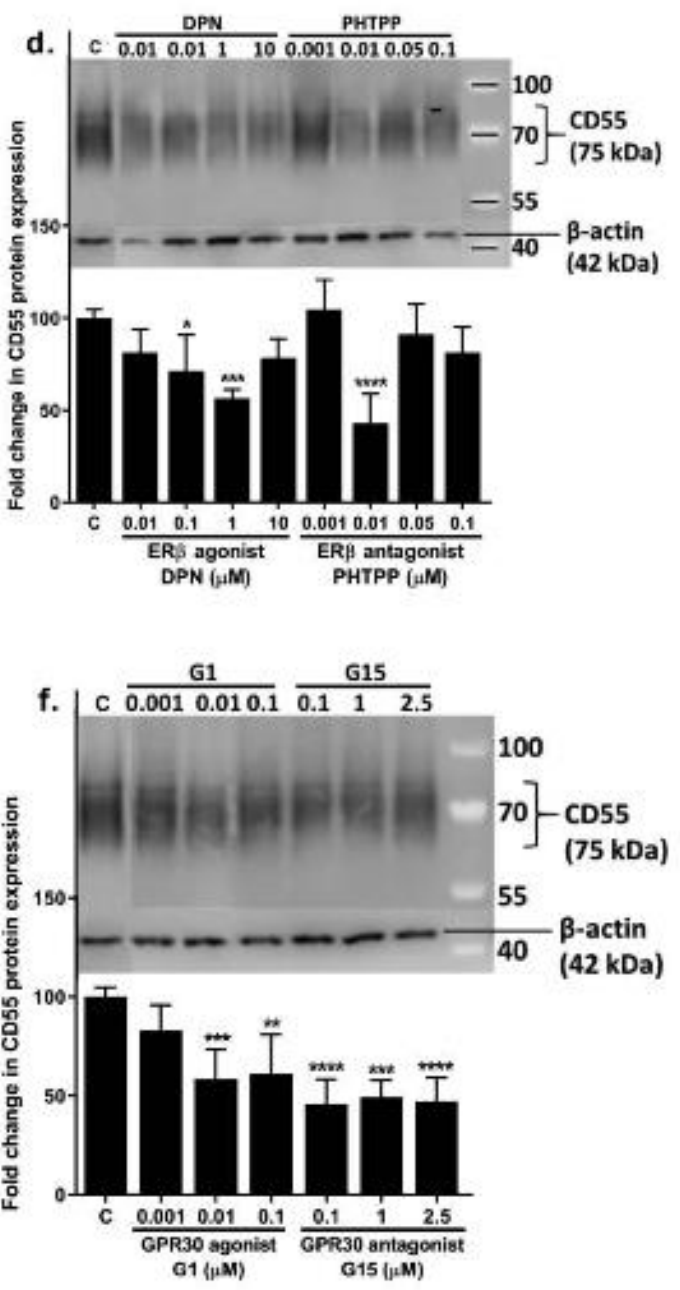
Figure 4: Relative expression of $c d 55$ mRNA and CD55 protein in HBEC 5637 cells pretreated with (a and b), ERa agonist PPT and ERo antagonist MPP, (c and d) ERß agonist DPN and ERß antagonist PHTPP, (e and f) GPR30 agonist G1 and GPR30 antagonist G15. CD55 mRNA or CD55 protein expression corresponded to bacterial invasion at each drug dose. $(* P<0.05, * * P<0.01, * * * P<0.001, * * * * P<0.0001$ indicate significant differences between drug treated groups and vehicle control $(C)$ group)

\subsection{Modulation of ER subtype activity in HBEC 5637 cells differentially regulates the} gene expression of cytokines tnfa and illo

Pro-inflammatory cytokine, $\mathrm{TNF} \alpha$, plays a major role in eliminating bacterial infections by inducing innate immunity resulting in local inflammation and neutrophil recruitment. In contrast, anti-inflammatory cytokine, IL10 suppresses local inflammation, thus restoring homeostasis after bacterial infections are cleared. In our previous experiments, we observed differential protection against bacterial invasion that was induced by specific ER subtype agonists and antagonists. Hence, we investigated the effects of ER subtype specific agonists and antagonists on TNF $\alpha$ and IL10 cytokine gene expression in bladder cells before and after bacterial infection.

In uninfected HBEC 5637 cells, PPT treatment of cells induced a significant increase in tnfa mRNA expression at doses $0.01 \mu \mathrm{M}(\mathrm{P}<0.0001), 0.1 \mu \mathrm{M}(\mathrm{P}<0.0001)$ and $1 \mu \mathrm{M}(\mathrm{P}$ $<0.001$ ) (Figure 5 a). However, PPT resulted in a significant decrease of illo mRNA expression at all doses $(\mathrm{P}<0.0001)$ (Figure 5 a). In contrast, MPP treatment in uninfected cells significantly inhibited tnfa mRNA expression at doses $0.01 \mu \mathrm{M}(\mathrm{P}<0.01), 0.1 \mu \mathrm{M}$ $(\mathrm{P}<0.05)$ and $1 \mu \mathrm{M}(\mathrm{P}<0.001)$ but significantly increased $(\mathrm{P}<0.001)$ illo mRNA expression at all doses when compared to PPT treated group, explaining the reversal of PPT-mediated protection against bacterial invasion (Figure 5 a). 
Post-infection, the tnfa mRNA expression in PPT treated cells reduced significantly, when compared to control at all doses, $0.01 \mu \mathrm{M}(\mathrm{P}<0.05), 0.1 \mu \mathrm{M}(\mathrm{P}<0.0001)$ and $1 \mu \mathrm{M}(\mathrm{P}<$ 0.001) (Figure $5 \mathrm{~b}$ ). However, the $i l 10 \mathrm{mRNA}$ expression in these cells significantly increased $(\mathrm{P}<0.0001)$ at all doses (Figure $5 \mathrm{~b}$ ). In contrast, tnfa mRNA expression in MPP treated cells increased after infection but were still significantly lower than the control at all doses, $0.01 \mu \mathrm{M}(\mathrm{P}<0.001), 0.1 \mu \mathrm{M}(\mathrm{P}<0.001)$ and $1 \mu \mathrm{M}(\mathrm{P}<0.0001)$ (Figure $5 \mathrm{~b})$. Post-infection, the illo mRNA expression was significantly reduced $(\mathrm{P}<0.01)$ in MPP treated cells (Figure $5 \mathrm{~b}$ ), when compared to control and PPT treated cells explaining the higher bacterial invasion observed in MPP treated cells.

In uninfected cells, ER $\beta$ agonist, DPN treatment significantly increased tnfa mRNA expression only at doses $0.1 \mu \mathrm{M}(\mathrm{P}<0.05)$ and $0.01 \mu \mathrm{M}$, but the thfa mRNA expression at doses $1 \mu \mathrm{M}$ or $10 \mu \mathrm{M}$ were comparable to control (Figure $5 \mathrm{c}$ ). However, DPN treatment in uninfected cells significantly reduced $(\mathrm{P}<0.0001)$ illo mRNA expression at doses 0.01 $\mu \mathrm{M}, 1 \mu \mathrm{M}$ and $10 \mu \mathrm{M}$, but the expression at $0.1 \mu \mathrm{M}$ was comparable to control (Figure 5 c). In contrast, ER $\beta$ antagonist, PHTPP treatment of cells significantly reduced tnfa mRNA expression in cells at all doses $0.001 \mu \mathrm{M}(\mathrm{P}<0.001), 0.01 \mu \mathrm{M}(\mathrm{P}<0.01), 0.05 \mu \mathrm{M}(\mathrm{P}<$ $0.01)$ and $0.1 \mu \mathrm{M}(\mathrm{P}<0.0001)$ when compared to control (Figure $5 \mathrm{c})$. However, PHTPP treatment of cells increased illo mRNA expression only at $0.001 \mu \mathrm{M}$, but significantly reduced $(\mathrm{P}<0.05)$ illo mRNA expression at $0.01 \mu \mathrm{M}$ and $0.05 \mu \mathrm{M}$ (Figure $5 \mathrm{c}$ ). The illo mRNA expression in response to $0.1 \mu \mathrm{M}$ PHTPP was comparable to control. Further, tnfa mRNA expression levels observed in response to different doses of PHTPP treatment were 
still lower than the expression levels observed with DPN treatment. Also, illo mRNA expression levels observed in response to PHTPP treatment of cells at different doses were higher than the expression levels observed with DPN treatment. These opposite effects on tnfa and illo mRNA expression in DPN versus PHTPP treated bladder cells explain the protective effects of DPN against bacterial invasion when compared to PHTPP treated cells.

Post-infection, the tnfa mRNA expression levels were significantly lower in both DPN and PHTPP treated cells at all doses $(\mathrm{P}<0.0001)$ compared to control (Figure $5 \mathrm{~d}$ ). However, tnfa mRNA expression levels observed in DPN treated infected cells were comparable to the levels observed in PHTPP treated infected cells. The illo mRNA expression in DPN treated infected cells was significantly reduced at doses $0.01 \mu \mathrm{M}(\mathrm{P}<0.0001)$ and $1 \mu \mathrm{M}$ $(\mathrm{P}<0.01)$, but the expression levels at $0.1 \mu \mathrm{M}$ and $10 \mu \mathrm{M}$ DPN treatment were comparable to control. In contrast, illo mRNA expression levels in PHTPP treated infected cells were higher than control at doses $0.001 \mu \mathrm{M}(\mathrm{P}<0.05), 0.05 \mu \mathrm{M}$ and $0.1 \mu \mathrm{M}(\mathrm{P}<0.01)$, but comparable to control at $0.01 \mu \mathrm{M}$. Also, the illo mRNA expression levels in DPN treated infected cells were lower than the expression levels in PHTPP treated infected cells.

In uninfected HBEC 5637 cells, GPR30 agonist, G1 treatment led to a significantly low tnfa mRNA expression at all doses $(\mathrm{P}<0.0001)$ when compared to control (Figure $5 \mathrm{e})$. No changes in illo mRNA expression were observed in response to G1 treatment in these cells (Figure 5 e). In contrast, GPR30 antagonist, G15 treatment of cells increased tnfa 
mRNA expression levels and reduced $i l 10$ mRNA expression levels when compared to G1 treatment (Figure 5 e).

Post-infection, tnfa mRNA expression in cells were minimally higher in G1 treated groups when compared to control (Figure $5 \mathrm{f}$ ). In contrast, the illo mRNA expression in these cells significantly reduced with $\mathrm{G} 1$ treatment at doses $0.01 \mu \mathrm{M}$ and $0.1 \mu \mathrm{M}(\mathrm{P}<0.0001)$ (Figure $5 \mathrm{f}$ ). However, thfa mRNA expression levels significantly reduced in G15 treated infected cells at doses $0.1 \mu \mathrm{M}(\mathrm{P}<0.01), 1 \mu \mathrm{M}$ and $2.5 \mu \mathrm{M}$ when compared to control $(\mathrm{P}<0.0001)$, but the $i l 10$ mRNA expression significantly increased in these cells at doses $0.1 \mu \mathrm{M}(\mathrm{P}<$ 0.01), $1 \mu \mathrm{M}(\mathrm{P}<0.05)$ and $2.5 \mu \mathrm{M}(\mathrm{P}<0.001)$ when compared to control (Figure $5 \mathrm{f})$. These opposite effects of G1 or G15 treatment on thfa and illo mRNA expression in infected cells corresponded with the bacterial invasion outcome that was observed in response to treatment with these drugs. 
a.

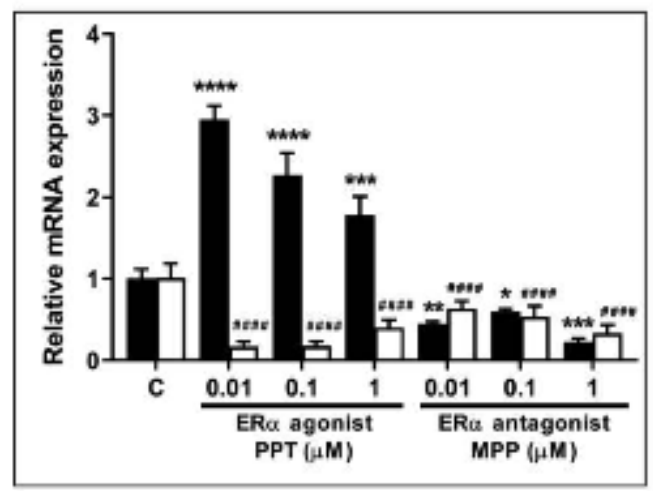

c.

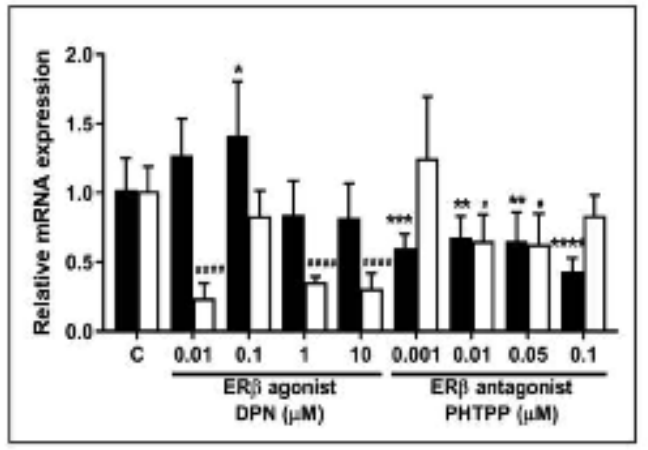

e.

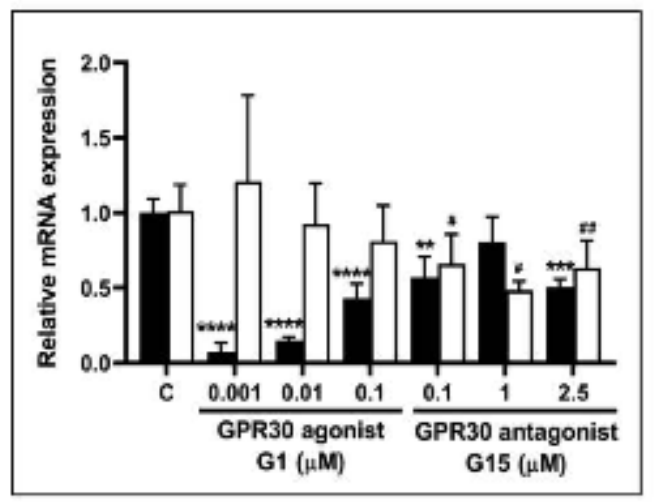

b.

TNF $\alpha$
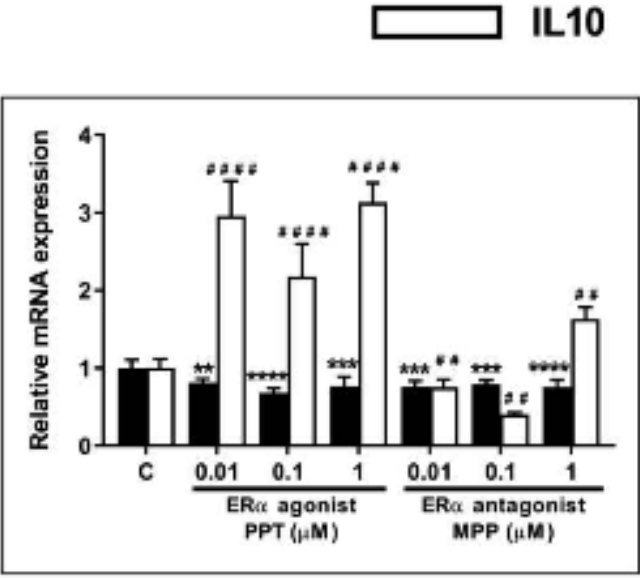

d.

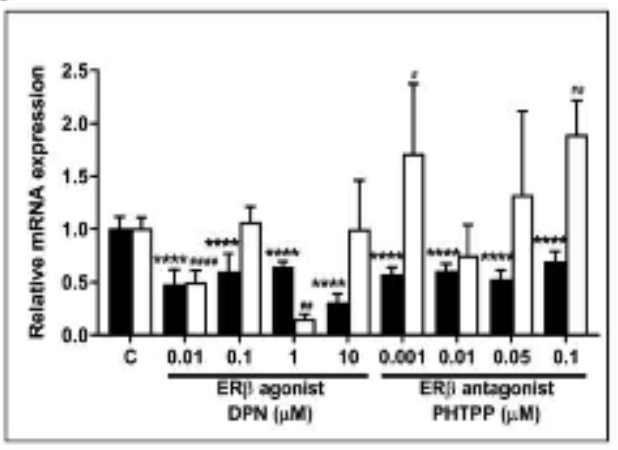

f.

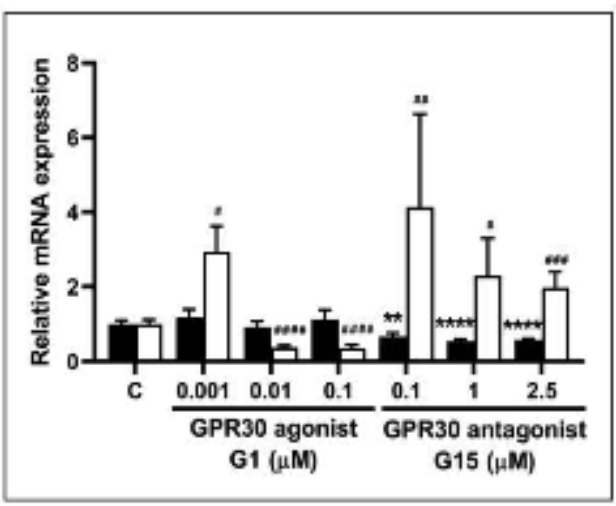

Figure 5: Relative expression of $t$ f $f a$ and $i l 10 \mathrm{mRNA}$ before and after infection in HBEC 5637 cells pre-treated with (a and b), ER $\alpha$ agonist PPT and ER $\alpha$ antagonist MPP, (c and d) ERß agonist DPN and ER $\beta$ antagonist PHTPP, (e and $f$ ) GPR30 agonist G1 and GPR30 antagonist G15. tnfa mRNA expression before infection corresponded to bacterial invasion at each drug dose. $(* P<0.05, * * P<0.01, * * * P<0.001, * * * * P<0.0001$, indicate significant differences between tnfa $m R N A$ expression in drug treated groups and vehicle control $(C)$ group. \#P<0.05, \#\#P<0.01, \#\# 
$\# P<0.001, \# \# \# P<0.0001$, indicate significant differences between illo mRNA expression in drug treated groups and vehicle control (C) group).

\section{6. siRNA-mediated targeting of esr1 mRNA in HBEC 5637 cells leads to suppression}

\section{of ER $\alpha$ expression}

Our results from the Dr E. coli bacterial invasion studies in HBEC 5637 cells showed that ER $\alpha$ agonist was the most protective against the bacterial invasion followed by ER $\beta$ agonist and GPR30 antagonist. A complete reversal of this protection against bacterial invasion was observed only in response to treatment with ER $\beta$ antagonist and GPR30 agonist. However, ER $\alpha$ antagonist, MPP only showed partial reversal of protection mediated by ER $\alpha$ agonist, PPT against bacterial invasion. Hence, to further confirm these results related to ER $\alpha$, direct silencing of esrl gene expression using siRNA was undertaken in 5637 bladder cells before infection with Dr E. coli.

Our results showed a significant decrease $(\mathrm{P}<0.0001)$ in esrl mRNA (Figure 6 a) expression levels and ER $\alpha$ protein (Figure $6 \mathrm{~b}$ and $\mathrm{c}$ ) expression in cells treated with siRNA as compared to no treatment control or negative control (treated with non-specific RNA). 
a.

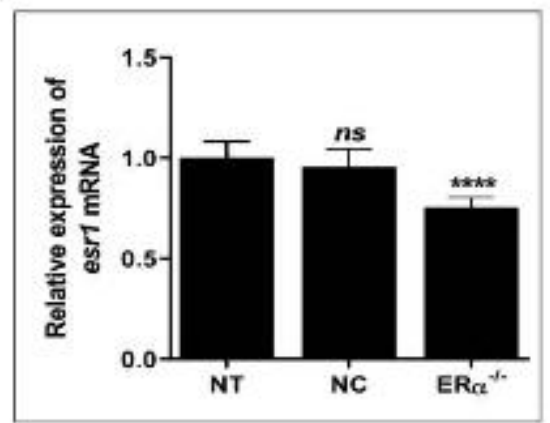

b.
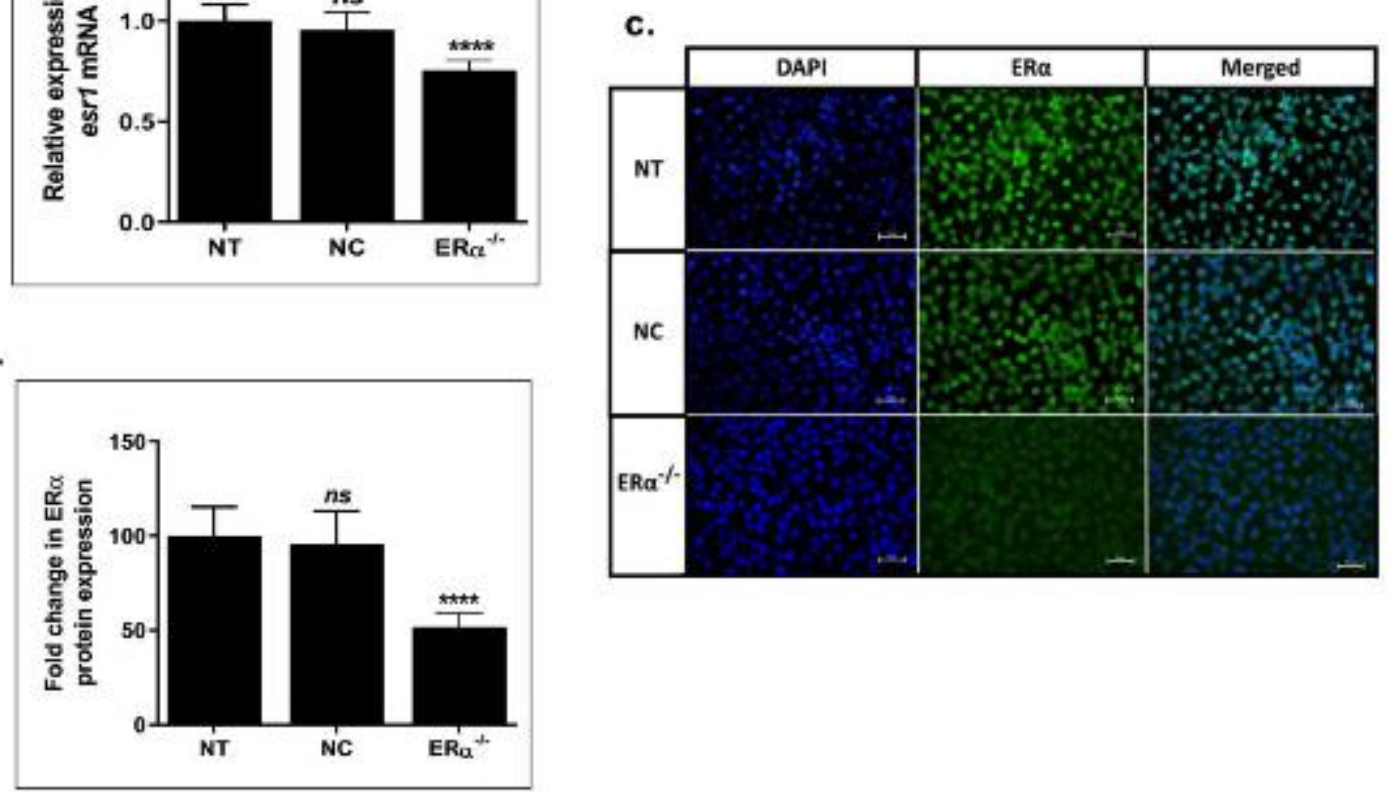

Figure 6: Silencing of ERa protein in HBEC 5637 cells using siRNA. Expression of (a) esrl mRNA and (b) ER $\alpha$ protein significantly reduced in cells treated with $\mathrm{ER} \alpha$ siRNA as compared to no treatment (NT) control and negative control (NC) cells treated with non-specific siRNA. (c) Representative images showing reduction of ER $\alpha$ protein detected by immunofluorescence staining. ( $* * * * P<0.0001$, indicate significant differences relative to no treatment control $(N T)$, nsnot significant. 


\section{7. siRNA-induced silencing of esr1 gene expression in HBEC 5637 cells lead to increased bacterial invasion and CD55 expression}

We determined the effects of esrl gene silencing on Dr E. coli invasion in HBEC 5637 cells. Silencing of esrl gene in these cells significantly increased $(\mathrm{P}<0.0001)$ Dr E. coli invasion by $180 \%$ when compared to both the controls (Figure 7 a), indicating the protective role of ER $\alpha$ against Dr E. coli invasion. Silencing of esrl in cells did not affect the expression of $c d 55$ mRNA (Figure $7 \mathrm{~b}$ ), however CD55 protein expression was found to be significantly increased $(\mathrm{P}<0.05)$ in esr 1 -/ 5637 cells when compared to both control groups (Figure $7 \mathrm{c}$ ). This further explains the increased bacterial invasion that was observed in $\operatorname{esr} 1$ - cells.

a.
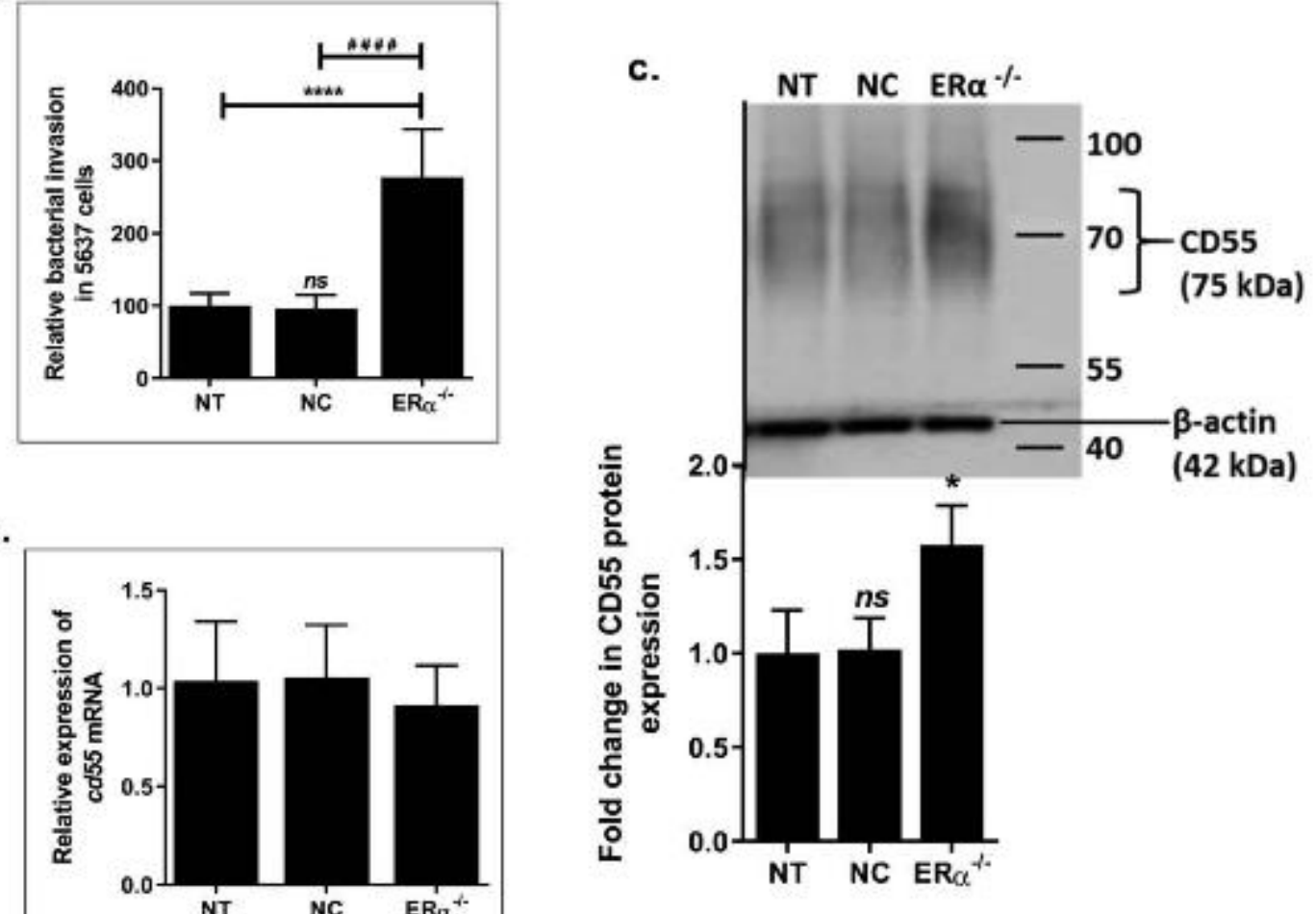

Figure 7: Relative invasion by Dr E. coli (a) and relative expression of CD55 (b) mRNA and (c) protein in ERa-- HBEC 5637 cells. Bacterial invasion and CD55 mRNA and protein 
expression in ER $\alpha-1-$ cells were significantly higher as compared to both controls. $(* P<0.05$, $* * * * P<0.0001$, indicate significant differences relative to no treatment control (NT), ns- not significant).

3.8. siRNA-induced silencing of ERa in HBEC 5637 cells differentially regulates the gene expression of cytokines tnfa and il10

The tnfa and illo mRNA expression levels in esrl-/- cells were determine before (Figure 8 a) and after (Figure $8 \mathrm{~b}$ ) infection. In uninfected state, thfa mRNA expression in esr 1 - cells were significantly suppressed $(\mathrm{P}<0.0001)$ and the $i l 10$ mRNA expression levels were significantly elevated $(\mathrm{P}<0.05)$ when compared to controls. Low tnfa mRNA expression levels and high illo mRNA expression levels in esr 1-/- cells explain the observed high Dr E. coli invasion in these cells. The tnfa mRNA expression levels in infected esr 1 - cells were significantly suppressed $(\mathrm{P}<0.01)$ but not to the extent as observed in uninfected esrl-- cells. However, the illo mRNA expression levels were found to be significantly low $(\mathrm{P}<0.01)$ when compared to controls.

a.

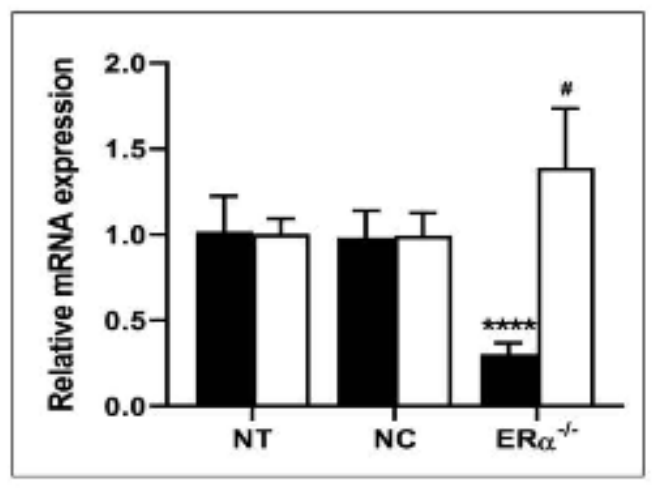

b.

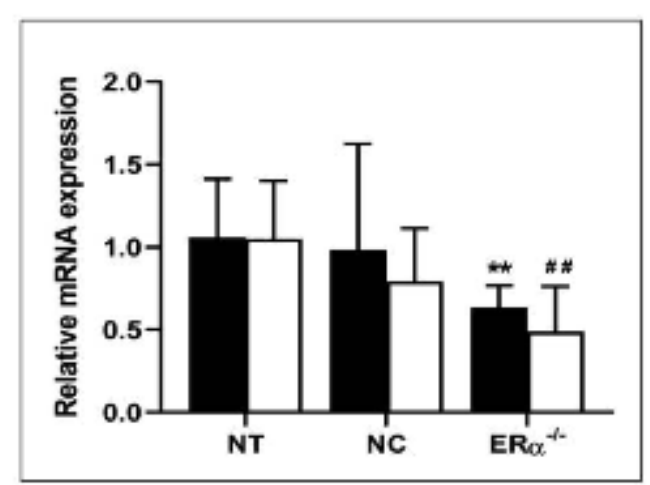

Figure 8: Relative expression of $t$ f $f a$ and $i l 10$ mRNA in ERo-/.HBEC 5637 cells (a) before and (b) after infection. Expression of tnfa and illo mRNA in ER $\alpha-$ - cells were significantly lower as compared to both controls. ( $* * P<0.01$, ****P<0.0001, indicate significant differences between 
tnfa mRNA expression in siRNA treated groups and no treatment control (NT) group. \#P<0.05, \# $\# P<0.01$, indicate significant differences between illo mRNA expression in siRNA treated groups and no treatment control (NT) group).

\section{Discussion:}

The development of early innate immune responses in the bladder epithelium serves as the first line of defense against colonization and invasion by uropathogens thus dictating the UTI disease outcome. Some of the uropathogens, like Dr E. coli bind to bladder and kidney cells under the influence of hormones, thus any acute changes in host hormones like estrogen or progesterone increase the susceptibility of women to UTIs by these bacteria 1, 16, 17, 44. Estrogen has immunomodulatory effects on the epithelium and other immune cells mediating actions via ER subtypes to finally affect expression of various innate immune factors. Varying tissue specific distribution of the ER subtypes has been reported 45-51, including the bladder 52-56. Nuclear ER subtypes bind to estrogen responsive elements (EREs) in the promoter region of cytokines to induce cytokine gene transcription, thereby modulating the inflammation 37,51. However, the contributions of ER subtypes in regulating the bacterial colonization or regulation of pro-inflammatory or anti-inflammatory responses in the bladder for affecting the bacterial colonization or clearance have not been studied.

The objective of the current study was to establish an in vitro UTI model in HBEC 5637 cells to understand the involvement of ER subtypes in modulating early innate immune responses and regulating Dr E. coli colonization and infection outcome. The presence of Dr E. coli colonizing factor CD55 was confirmed on these cells to ensure effective 
colonization by these bacteria. In addition, the presence of all three ER subtypes was also confirmed on HBEC 5637 cells. Among the ERs, the relative expression of GPR30 was the highest followed by ER $\beta$ when compared to ER $\alpha$. This is the first study reporting the expression of GPR30 and Dr E. coli colonization receptor, CD55 on HBEC 5637 cells. We also confirmed that the presence of both host cell CD55 and bacterial Dr fimbriae were required for Dr E. coli invasion in HBEC cells.

ER subtype modulation by specific agonist or antagonist treatment of HBEC 5637 cells resulted in differential expression of bacterial colonization receptor CD55, impacting the invasion by Dr E. coli in these cells. The hormonal drug effects on these cells also led to differential thfa and $i l 10$ gene expression. Activation of ER $\alpha$ by PPT in 5637 cells resulted in significantly reduced bacterial invasion by $70-85 \%$, and this protection was partially reversed by ER $\alpha$ antagonist MPP. The PPT-mediated protection against bacterial invasion can be explained by the observed downregulation of CD55 and IL10 and the upregulation of TNF $\alpha$ gene expression in PPT treated uninfected cells. In contrast, suppression of ER $\alpha$ in bladder cells by MPP led to upregulation of CD55 and IL10 and downregulation of $\mathrm{TNF} \alpha$ gene expression. These results are in contrast to our observations made in the mouse bladder in our in vivo UTI model study 36, where MPP drug treatment showed relatively more protection against Dr E. coli invasion in the bladder than PPT. These protective effects of MPP in the mouse bladder were mediated by downregulation of CD55 and upregulation of TNF $\alpha$ expression. The conflicting results observed in mouse bladder tissue versus human bladder cells may be attributed to variability of distribution and action of ER subtypes in the bladder of two species. Further, the gene expression patterns of TNF $\alpha$ and 
IL10 were found to be reversed in PPT treated infected cells. The opposing gene expression of these two pro and anti-inflammatory cytokines may be the result of bladder cells undergoing the bacterial clearance and also the subsequent restoration to the homeostasis state. CD55 expression in the infected cells was not determined as CD55 is often cleaved off from the infected cells.

ER $\beta$ activation in the bladder cells by DPN significantly reduced Dr E. coli invasion by 30-70\%, however to a lesser extent than observed with ER $\alpha$ agonist, PPT. DPN-induced protection in these bladder cells was completely reversed by ER $\beta$ antagonist, PHTPP. The reduced bacterial invasion observed in DPN treated cells was facilitated by downregulation of CD55 and IL10 and upregulation of TNF $\alpha$ gene expression observed in the uninfected state. However, the suppression of ER $\beta$ by PHTPP treatment in these cells resulted in the upregulation of CD55 and IL10 gene expression at some of the PHTPP doses and downregulation of TNF $\alpha$ gene expression in the uninfected state, that led to an increased bacterial invasion as observed in the infected cells.

In contrast to the actions of ER $\alpha$ and ER $\beta$ agonists, GPR30 agonist, G1 treatment in HBEC 5637 cells increased CD55 and IL10 gene expression but decreased TNF $\alpha$ expression in uninfected cells, leading to high bacterial invasion by Dr E. coli. To our surprise, blocking of GPR30 receptor by its antagonist G15 reduced CD55 and IL10 gene expression but increased the TNF $\alpha$ expression in the bladder cells, which reduced Dr E. coli invasion by $20-50 \%$ in the infected cells. However, this protection mediated by G15 against bacterial 
invasion was lesser than the protection mediated by ER $\alpha$ agonist, PPT. The TNF $\alpha$ and IL10 gene expression patterns were reversed in G15 treated infected cells that showed efficient bacterial clearance and restoration of homeostasis.

In summary, our results show that the nuclear estrogen receptors, ER $\alpha$ and ER $\beta$ mediate protection against Dr E. coli invasion in HBEC cells by downregulating CD55 and IL10 but upregulating TNF $\alpha$ gene expression. Further, we also demonstrate an opposing role played by the membrane receptor, GPR30 in these bladder cells with respect to the other two ER subtypes in mediating protection against Dr E. coli invasion by modulating the innate immune responses. Our siRNA transfection studies in HBEC 5637 cells further confirmed the protective role of ER $\alpha$ against bacterial invasion and its immunomodulatory effects on innate immune responses. Silencing of ER $\alpha$ by siRNA in HBEC 5637 cells led to significantly high CD55 and IL10 gene expression and suppressed pro-inflammatory $\mathrm{TNF} \alpha$ gene expression which were responsible for the observed high bacterial invasion in esrl-_ HBEC 5637 cells, further confirming the protective role of ER $\alpha$ in bladder cells. However, ER $\alpha$ antagonist, MPP induced only a partial protection and modulation of TNF $\alpha$ and IL10 gene expression in HBEC 5637 cells compared to PPT and that may be due to the limitation of the doses selected for the experiments.

These diverse immunomodulatory effects of the ER subtypes in the bladder cells may be a result of their differential gene transcription and signaling mechanisms at the cellular level, thus affecting the innate immunity 37. Though ER $\alpha$ and $\operatorname{ER} \beta$ are mostly known to have 
antagonistic effects on each other 57-60, some studies have shown that they cross-talk to produce a cumulative effect as observed in our studies 61-64. Depending on the cell type and the inflammatory milieu, these nuclear receptors can have both pro- and anti-inflammatory effects 40,65-68, by modulating the expression of important cytokines like TNF $\alpha$. The antiinflammatory effects that were observed in our study as a result of GPR30 activation by G1 have also been reported in two separate in vivo studies conducted in male mice and diabetic rats where production of IL10 was observed affecting the T-helper 17 cells 69, 70 Further, our results with G15 antagonist were supported in the recent in vitro and in vivo mouse brain studies. Pro-inflammatory responses were observed in rat microglial cells treated with G15 or by siRNA-mediated gperl gene knockdown 71 and also in GPR30 knockout mice 72. Similarly, in our recent studies in human A431 cuteneous squamous carcinoma cells, the agonist-based activation of ER $\alpha, E R \beta$ and GPR30 differentially upregulated CD55 expression that was downregulated by actions of their specific antagonists 73 .

Some of the recent studies have reported the possibility of cross-talk between GPR30 and the nuclear ERs (ER $\alpha$ and ER $\beta)$ in various cell types such as human breast cancer cells and monocytes 74-76. Other studies have reported that GPR30 can either have compensatory effects for the absence of nuclear ERs or antagonistic effects in the presence of nuclear ER subtypes as observed in nuclear ER positive and negative breast cancer cell lines 77, 78. 


\section{Conclusions}

In summary, this is the first study reporting the differential role of nuclear versus membrane ER subtypes in mediating protection against Dr E. coli invasion in human bladder cells via modulation of innate immune molecules, CD55, TNF $\alpha$ and IL10 expression. Estradiol regulation of TNF $\alpha$ expression has been reported in ER subtype positive breast cancer cells 79, 80. Further, we also report for the first time the ER subtype-mediated inverse regulation of CD55 and TNF $\alpha$ but a direct regulation of CD55 and IL10 gene expression in uninfected bladder cells under the homeostasis state. To maintain the homeostasis state and to avoid hyper activation or suppression of inflammation at the barrier sites in healthy individuals, it is crucial to regulate the expression of TNF $\alpha$ and IL10 25. These opposite trends in TNF $\alpha$ and IL10 expression have also been reported in the gastrointestinal tissues of normal and Irritable Bowel Syndrome patients showing the variable expression levels of ER subtypes 35.

Further studies are needed to investigate the ER-regulated downstream signaling in human bladder epithelial cells that result in boosting the innate immune responses and expelling uropathogens.

Our results may have important clinical significance for discovering new ER-subtype based approaches for generating innate immune responses in the bladder. In addition, the ER subtypes can serve as future targets for developing various novel therapies for mediating bacterial clearance in the bladder by boosting the innate immune responses against recurrent UTIs. In the absence of any viable vaccine and the rising number of multi-drug resistant UPEC strains, such novel therapies may have a huge potential for bringing a 
paradigm shift towards the development of non-antibiotic based therapies that are highly needed for dealing with the pathogenesis of UTIs.

\section{Acknowledgements}

We would also like to thank Batuel Okda for technical assistance in cell culture experiments. The authors would like to specially thank Dr. Subhas Das for sharing his technical expertise in molecular biology.

\section{Funding}

This project was supported by Cancer Sucks Inc., Bixby, Oklahoma to R.K., and Oklahoma State University Center for Health Sciences-Biomedical Sciences Graduate Program Research assistantship to A.S.

\section{References}

1. Kaul AK, Khan S, Martens MG, Crosson JT, Lupo VR and Kaul R. Experimental gestational pyelonephritis induces preterm births and low birth weights in $\mathrm{C} 3 \mathrm{H} / \mathrm{HeJ}$ mice. Infect Immun. 1999; 67: 5958-66.

2. Gilbert NM, O'Brien VP, Hultgren S, Macones G, Lewis WG and Lewis AL. Urinary tract infection as a preventable cause of pregnancy complications: opportunities, challenges, and a global call to action. Glob Adv Health Med. 2013; 2: 59-69.

3. MacLean AB. Urinary tract infection in pregnancy. Int J Antimicrob Agents. 2001; 17: 273-6;

4. Dwyer PL and O'Reilly M. Recurrent urinary tract infection in the female. Curr Opin Obstet Gynecol. 2002; 14: 537-43.

5. Stamm WE and Raz R. Factors contributing to susceptibility of postmenopausal women to recurrent urinary tract infections. Clin Infect Dis. 1999; 28: 723-5. 
6. Song $\mathrm{J}$ and Abraham SN. Innate and adaptive immune responses in the urinary tract. Eur J Clin Invest. 2008; 38 Suppl 2: 21-8.

7. Abraham SN and Miao Y. The nature of immune responses to urinary tract infections. Nat Rev Immunol. 2015; 15: 655-63.

8. Mulvey MA, Schilling JD and Hultgren SJ. Establishment of a persistent Escherichia coli reservoir during the acute phase of a bladder infection. Infect Immun. 2001; 69: 4572-9.

9. Duell BL, Carey AJ, Dando SJ, Schembri MA and Ulett GC. Human bladder uroepithelial cells synergize with monocytes to promote IL-10 synthesis and other cytokine responses to uropathogenic Escherichia coli. PLoS One. 2013; 8: e78013.

10. Duell BL, Carey AJ, Tan CK, et al. Innate transcriptional networks activated in bladder in response to uropathogenic Escherichia coli drive diverse biological pathways and rapid synthesis of IL-10 for defense against bacterial urinary tract infection. J Immunol. 2012; 188: 781-92.

11. Scott VC, Haake DA, Churchill BM, Justice SS and Kim JH. Intracellular Bacterial Communities: A Potential Etiology for Chronic Lower Urinary Tract Symptoms. Urology. 2015; 86: 425-31.

12. Luthje $\mathrm{P}$ and Brauner A. Virulence factors of uropathogenic E. coli and their interaction with the host. Adv Microb Physiol. 2014; 65: 337-72.

13. Pham T, Kaul A, Hart A, et al. dra-related X adhesins of gestational pyelonephritisassociated Escherichia coli recognize SCR-3 and SCR-4 domains of recombinant decayaccelerating factor. Infect Immun. 1995; 63: 1663-8.

14. Raz R. Urinary tract infection in postmenopausal women. Korean J Urol. 2011; 52: 8018.

15. Kaul AK, Kumar D, Nagamani M, Goluszko P, Nowicki S and Nowicki BJ. Rapid cyclic changes in density and accessibility of endometrial ligands for Escherichia coli Dr fimbriae.

Infect Immun. 1996; 64: 611-5.

16. Luthje P, Brauner H, Ramos NL, et al. Estrogen supports urothelial defense mechanisms. Sci Transl Med. 2013; 5: 190ra80.

17. Wang C, Symington JW, Ma E, Cao B and Mysorekar IU. Estrogenic modulation of uropathogenic Escherichia coli infection pathogenesis in a murine menopause model. Infect Immun. 2013; 81: 733-9.

18. Ingersoll MA and Albert ML. From infection to immunotherapy: host immune responses to bacteria at the bladder mucosa. Mucosal Immunol. 2013; 6: 1041-53.

19. Mohkam M, Asgarian F, Fahimzad A, Sharifian M, Dalirani R and Abdollah Gorgi F.

Diagnostic potential of urinary tumor necrosis factor-alpha in children with acute pyelonephritis. Iran J Kidney Dis. 2009; 3: 89-92.

20. Neni Susilaningsih BJK, Ratna Damma Purnawati. Production of tumor necrosis factor-á is increased in urinary tract infections. UNIVERSA MEDICINA. 2012; 31: 167-74.

21. Shang Z, Li Y, Hsu I, et al. Targeting estrogen/estrogen receptor alpha enhances Bacillus Calmette-Guerin efficacy in bladder cancer. Oncotarget. 2016; 7: 27325-35.

22. Sfikakis PP and Tsokos GC. Towards the next generation of anti-TNF drugs. Clin Immunol. 2011; 141: 231-5.

23. Chan CY, St John AL and Abraham SN. Mast cell interleukin-10 drives localized tolerance in chronic bladder infection. Immunity. 2013; 38: 349-59.

24. Couper KN, Blount DG and Riley EM. IL-10: the master regulator of immunity to infection. J Immunol. 2008; 180: 5771-7.

25. Hofmann SR, Rosen-Wolff A, Tsokos GC and Hedrich CM. Biological properties and regulation of IL-10 related cytokines and their contribution to autoimmune disease and tissue injury. Clin Immunol. 2012; 143: 116-27.

26. Tabibzadeh S, Satyaswaroop PG, von Wolff M and Strowitzki T. Regulation of TNFalpha mRNA expression in endometrial cells by TNF-alpha and by oestrogen withdrawal. $\mathrm{Mol}$ Hum Reprod. 1999; 5: 1141-9. 
27. Ito A, Bebo BF, Jr., Matejuk A, et al. Estrogen treatment down-regulates TNF-alpha production and reduces the severity of experimental autoimmune encephalomyelitis in cytokine knockout mice. J Immunol. 2001; 167: 542-52.

28. Straub RH. The complex role of estrogens in inflammation. Endocr Rev. 2007; 28: 521-

74.

29. An J, Ribeiro RC, Webb P, et al. Estradiol repression of tumor necrosis factor-alpha transcription requires estrogen receptor activation function-2 and is enhanced by coactivators. Proc Natl Acad Sci U S A. 1999; 96: 15161-6.

30. Zhao L, Gu C, Huang K, et al. Association between oestrogen receptor alpha (ESR1) gene polymorphisms and endometriosis: a meta-analysis of 24 case-control studies. Reprod Biomed Online. 2016; 33: 335-49.

31. Gori I, Pellegrini C, Staedler D, Russell R, Jan C and Canny GO. Tumor necrosis factoralpha activates estrogen signaling pathways in endometrial epithelial cells via estrogen receptor alpha. Mol Cell Endocrinol. 2011; 345: 27-37.

32. Srivastava S, Weitzmann MN, Cenci S, Ross FP, Adler S and Pacifici R. Estrogen decreases TNF gene expression by blocking JNK activity and the resulting production of c-Jun and JunD. J Clin Invest. 1999; 104: 503-13.

33. Roggia $\mathrm{C}$, Gao Y, Cenci $\mathrm{S}$, et al. Up-regulation of TNF-producing $\mathrm{T}$ cells in the bone marrow: a key mechanism by which estrogen deficiency induces bone loss in vivo. Proc Natl Acad Sci U S A. 2001; 98: 13960-5.

34. Rettew JA, McCall SHt and Marriott I. GPR30/GPER-1 mediates rapid decreases in TLR4 expression on murine macrophages. Mol Cell Endocrinol. 2010; 328: 87-92.

35. Jacenik D, Cygankiewicz AI, Fichna J, Mokrowiecka A, Malecka-Panas E and Krajewska WM. Estrogen signaling deregulation related with local immune response modulation in irritable bowel syndrome. Mol Cell Endocrinol. 2018; 471: 89-96.

36. Sen A, Iyer J, Boddu S, Kaul A and Kaul R. Estrogen receptor alpha differentially modulates host immunity in the bladder and kidney in response to urinary tract infection. Am J Clin Exp Urol. 2019; 7: 110-22.

37. Kovats S. Estrogen receptors regulate innate immune cells and signaling pathways. Cell Immunol. 2015; 294: 63-9.

38. Christaki E, Opal SM, Keith JC, Jr., et al. Estrogen receptor beta agonism increases survival in experimentally induced sepsis and ameliorates the genomic sepsis signature: a pharmacogenomic study. J Infect Dis. 2010; 201: 1250-7.

39. Heron PM, Turchan-Cholewo J, Bruce-Keller AJ and Wilson ME. Estrogen receptor alpha inhibits the estrogen-mediated suppression of HIV transcription in astrocytes: implications for estrogen neuroprotection in HIV dementia. AIDS Res Hum Retroviruses. 2009; 25: 1071-81.

40. Soucy G, Boivin G, Labrie F and Rivest S. Estradiol is required for a proper immune response to bacterial and viral pathogens in the female brain. $J$ Immunol. 2005; 174: 6391-8. 41. Olde B and Leeb-Lundberg LM. GPR30/GPER1: searching for a role in estrogen physiology. Trends Endocrinol Metab. 2009; 20: 409-16.

42. Windahl SH, Andersson N, Chagin AS, et al. The role of the G protein-coupled receptor GPR30 in the effects of estrogen in ovariectomized mice. Am J Physiol Endocrinol Metab. 2009; 296: E490-6.

43. Goluszko P, Popov V, Selvarangan R, Nowicki S, Pham T and Nowicki BJ. Dr fimbriae operon of uropathogenic Escherichia coli mediate microtubule-dependent invasion to the HeLa epithelial cell line. J Infect Dis. 1997; 176: 158-67.

44. Foust-Wright CE, Pulliam SJ, Batalden RP, et al. Hormone Modulation of Toll-Like Receptor 5 in Cultured Human Bladder Epithelial Cells. Reprod Sci. 2017; 24: 713-9.

45. Couse JF, Lindzey J, Grandien K, Gustafsson JA and Korach KS. Tissue distribution and quantitative analysis of estrogen receptor-alpha (ERalpha) and estrogen receptor-beta (ERbeta) 
messenger ribonucleic acid in the wild-type and ERalpha-knockout mouse. Endocrinology. 1997; 138: 4613-21.

46. Osterlund MK, Gustafsson JA, Keller E and Hurd YL. Estrogen receptor beta (ERbeta) messenger ribonucleic acid (mRNA) expression within the human forebrain: distinct distribution pattern to ERalpha mRNA. J Clin Endocrinol Metab. 2000; 85: 3840-6.

47. Saunders PT. Oestrogen receptor beta (ER beta). Rev Reprod. 1998; 3: 164-71.

48. Saunders PT, Fisher JS, Sharpe RM and Millar MR. Expression of oestrogen receptor beta (ER beta) occurs in multiple cell types, including some germ cells, in the rat testis. $J$ Endocrinol. 1998; 156: R13-7.

49. Saunders PT, Maguire SM, Gaughan J and Millar MR. Expression of oestrogen receptor beta (ER beta) in multiple rat tissues visualised by immunohistochemistry. J Endocrinol. 1997; 154: R13-6.

50. Taylor AH and Al-Azzawi F. Immunolocalisation of oestrogen receptor beta in human tissues. J Mol Endocrinol. 2000; 24: 145-55.

51. Monteiro R, Teixeira D and Calhau C. Estrogen signaling in metabolic inflammation. Mediators Inflamm. 2014; 2014: 615917.

52. Tincello DG, Taylor AH, Spurling SM and Bell SC. Receptor isoforms that mediate estrogen and progestagen action in the female lower urinary tract. J Urol. 2009; 181: 1474-82. 53. Kauffman EC, Robinson BD, Downes M, et al. Estrogen receptor-beta expression and pharmacological targeting in bladder cancer. Oncol Rep. 2013; 30: 131-8.

54. Makela S, Strauss L, Kuiper G, et al. Differential expression of estrogen receptors alpha and beta in adult rat accessory sex glands and lower urinary tract. Mol Cell Endocrinol. 2000; 170: $219-29$.

55. Carley ME, Rickard DJ, Gebhart JB, Webb MJ, Podratz KC and Spelsberg TC. Distribution of estrogen receptors alpha and beta mRNA in mouse urogenital tissues and their expression after oophorectomy and estrogen replacement. Int Urogynecol J Pelvic Floor Dysfunct. 2003; 14: 141-5.

56. Imamov O, Yakimchuk K, Morani A, et al. Estrogen receptor beta-deficient female mice develop a bladder phenotype resembling human interstitial cystitis. Proc Natl Acad Sci U S A. 2007; 104: 9806-9.

57. Chan KK, Leung TH, Chan DW, et al. Targeting estrogen receptor subtypes (ERalpha and ERbeta) with selective ER modulators in ovarian cancer. J Endocrinol. 2014; 221: 325-36. 58. Lewandowski SA, Thiery J, Jalil A, Leclercq G, Szczylik C and Chouaib S. Opposite effects of estrogen receptors alpha and beta on MCF-7 sensitivity to the cytotoxic action of TNF and p53 activity. Oncogene. 2005; 24: 4789-98.

59. Tiwari-Woodruff S, Morales LB, Lee R and Voskuhl RR. Differential neuroprotective and antiinflammatory effects of estrogen receptor (ER)alpha and ERbeta ligand treatment. Proc Natl Acad Sci U S A. 2007; 104: 14813-8.

60. Song X and Pan ZZ. Estrogen receptor-beta agonist diarylpropionitrile counteracts the estrogenic activity of estrogen receptor-alpha agonist propylpyrazole-triol in the mammary gland of ovariectomized Sprague Dawley rats. J Steroid Biochem Mol Biol. 2012; 130: 26-35.

61. Teng J, Wang ZY, Jarrard DF and Bjorling DE. Roles of estrogen receptor alpha and beta in modulating urothelial cell proliferation. Endocr Relat Cancer. 2008; 15: 351-64.

62. Evans MJ, Harris HA, Miller CP, Karathanasis SK and Adelman SJ. Estrogen receptors alpha and beta have similar activities in multiple endothelial cell pathways. Endocrinology. 2002; 143: 3785-95.

63. Abid S, Xie S, Bose M, et al. 17beta-Estradiol Dysregulates Innate Immune Responses to Pseudomonas aeruginosa Respiratory Infection and Is Modulated by Estrogen Receptor Antagonism. Infect Immun. 2017; 85.

64. Yasar P, Ayaz G, User SD, Gupur G and Muyan M. Molecular mechanism of estrogenestrogen receptor signaling. Reprod Med Biol. 2017; 16: 4-20. 
65. Vegeto E, Bonincontro C, Pollio G, et al. Estrogen prevents the lipopolysaccharideinduced inflammatory response in microglia. J Neurosci. 2001; 21: 1809-18.

66. Pozzi S, Benedusi V, Maggi A and Vegeto E. Estrogen action in neuroprotection and brain inflammation. Ann N Y Acad Sci. 2006; 1089: 302-23.

67. Xing D, Feng W, Miller AP, et al. Estrogen modulates TNF-alpha-induced inflammatory responses in rat aortic smooth muscle cells through estrogen receptor-beta activation. Am J Physiol Heart Circ Physiol. 2007; 292: H2607-12.

68. Wang M, Crisostomo PR, Markel T, Wang Y, Lillemoe KD and Meldrum DR. Estrogen receptor beta mediates acute myocardial protection following ischemia. Surgery. 2008; 144: 2338.

69. Brunsing RL and Prossnitz ER. Induction of interleukin-10 in the T helper type 17 effector population by the $\mathrm{G}$ protein coupled estrogen receptor (GPER) agonist G-1. Immunology. 2011; 134: 93-106.

70. Azizian H, Khaksari M, Asadi Karam G, Esmailidehaj M and Farhadi Z.

Cardioprotective and anti-inflammatory effects of G-protein coupled receptor 30 (GPR30) on postmenopausal type 2 diabetic rats. Biomed Pharmacother. 2018; 108: 153-64.

71. Zhao TZ, Ding Q, Hu J, He SM, Shi F and Ma LT. GPER expressed on microglia mediates the anti-inflammatory effect of estradiol in ischemic stroke. Brain Behav. 2016; 6: e00449.

72. Sharma G, Hu C, Brigman JL, Zhu G, Hathaway HJ and Prossnitz ER. GPER deficiency in male mice results in insulin resistance, dyslipidemia, and a proinflammatory state.

Endocrinology. 2013; 154: 4136-45.

73. Lan J, Gao XH and Kaul R. Estrogen receptor subtype agonist activation in human cutaneous squamous cell carcinoma cells modulates expression of CD55 and Cyclin D1. EXCLI J. 2019; 18: 606-18.

74. Romano SN and Gorelick DA. Crosstalk between nuclear and G protein-coupled estrogen receptors. Gen Comp Endocrinol. 2018; 261: 190-7.

75. Arias-Pulido H, Royce M, Gong Y, et al. GPR30 and estrogen receptor expression: new insights into hormone dependence of inflammatory breast cancer. Breast Cancer Res Treat. 2010; 123: $51-8$.

76. Pelekanou V, Kampa M, Kiagiadaki F, et al. Estrogen anti-inflammatory activity on human monocytes is mediated through cross-talk between estrogen receptor ERalpha36 and GPR30/GPER1. J Leukoc Biol. 2016; 99: 333-47.

77. Pandey DP, Lappano R, Albanito L, Madeo A, Maggiolini M and Picard D. Estrogenic GPR30 signalling induces proliferation and migration of breast cancer cells through CTGF. EMBO J. 2009; 28: 523-32.

78. Ariazi EA, Brailoiu E, Yerrum S, et al. The G protein-coupled receptor GPR30 inhibits proliferation of estrogen receptor-positive breast cancer cells. Cancer Res. 2010; 70: 1184-94.

79. To SQ, Cheung V, Lazarus KA, Knower KC and Clyne CD. Estradiol regulates Tumor Necrosis Factor-alpha expression and secretion in Estrogen Receptor positive breast cancer cells. Mol Cell Endocrinol. 2014; 394: 21-8.

80. Medina-Estrada I, Alva-Murillo N, Lopez-Meza JE and Ochoa-Zarzosa A. Immunomodulatory Effects of 17beta-Estradiol on Epithelial Cells during Bacterial Infections. $J$ Immunol Res. 2018; 2018: 6098961. 